\title{
22. A ROCK-MAGNETIC RECORD OF MONSOONAL DUST DEPOSITION TO THE ARABIAN SEA: EVIDENCE FOR A SHIFT IN THE MODE OF DEPOSITION AT $2.4 \mathrm{Ma}^{1}$
}

\author{
Peter deMenocal, ${ }^{2}$ Jan Bloemendal, ${ }^{3}$ and John King ${ }^{3}$
}

\begin{abstract}
A detailed record of eolian deposition from the Asian monsoon has been determined from measurements of magnetic susceptibility at Sites 721 and 722 located on an elevated ridge in the western Arabian Sea. Susceptibility was measured at 5 -cm intervals $(1 \mathrm{k} . \mathrm{y}$.) on whole-core sections $(15,000$ measurements) and these data were used to construct complete composite records extending to $3.2 \mathrm{Ma}$. The composite records at Sites 721 and 722 are virtually identical, suggesting that both are complete and without local hiatuses. Bulk X-ray diffraction analyses indicate that (eolian) quartz and dolomite abundances are strongly covariant with the susceptibility data $(r=0.83,0.70 ; n=172)$. An almost perfect correlation $(r=0.98 ; n=94)$ between susceptibility and terrigenous percent (determined by sequential carbonate, opal, and organic carbon extraction) indicates that susceptibility is a rapid and sensitive tracer of terrigenous fraction variations. Furthermore, terrigenous and biogenic flux calculations indicate that the observed susceptibility variations are indeed the result of terrigenous accumulation rate variations and not dilution by variations in biogenic input.

In the frequency-domain, variance is concentrated at orbital periodicities for the entire $3.2 \mathrm{Ma}$ sequence; however, there is a shift in the dominant periodicity at ca. 2.4 Ma. From 3.2 to $2.4 \mathrm{Ma}$, the susceptibility data vary almost purely at 23-19 k.y. periodicities and coherency with the precessional insolation forcing is high (0.89). Strong and coherent variance at the 23-19 k.y. band is maintained after $2.4 \mathrm{Ma}$ but there is a dramatic increase in variance at the $41 \mathrm{k} . \mathrm{y}$. periodicity corresponding to orbital obliquity. The timing of this shift coincides with the initiation of Northern Hemisphere glaciation and suggests a linkage between high- and low-latitude climate processes. General circulation model experiments and paleoclimatological evidence from northeast Africa suggest that the increase in $41 \mathrm{k}$.y. power after $2.4 \mathrm{Ma}$ may be reflecting periodic increases in monsoon dust source area aridity due to the coeval expansion of the Eurasian and/or North American ice sheets, which varied predominantly at this periodicity.
\end{abstract}

\section{INTRODUCTION}

The seasonal reversal of atmospheric circulation and precipitation patterns associated with the Asian monsoon is one of the most distinctive climatic features of the tropics. The origin and dynamics of the Asian monsoon are complex, but observational and theoretical studies have provided a general understanding of its larger scale features (Hastenrath, 1985). Northern Hemisphere summer heating develops a strong low pressure cell over the Tibetan Plateau, which enables regional cyclonic circulation to prevail from May to September (Hastenrath and Lamb, 1979). In the northwest Arabian Sea, strong, moisture-laden southwest winds parallel the Arabian coast, bringing the monsoon rains to southern Asia (Fig. 1). Strong coastal upwelling off Arabia and Oman results from the eastward displacement of Arabian Sea surface waters by the wind stress curl.

The intensity of the summer monsoon has been tied to the orographic effects of the Himalayan Mountains and the Tibetan Plateau, which tend to enhance the convergence of moist convection and latent heat (Ramage, 1965; Hahn and Manabe, 1975). During the winter months, the land cools relative to the ocean, allowing a broad high-pressure cell to develop over the Tibetan Plateau and, to a lesser extent, over the Arabian Peninsula. The general winter season circulation in this region is anticyclonic, and orographic effects of the Tibetan Plateau and the regional Hadley circulation interact to produce dry, variable, and often intense northeast trade-wind flow over the south

\footnotetext{
${ }^{1}$ Prell, W. L., Niitsuma, N., et al., 1991. Proc. ODP, Sci. Results, 117: College Station, TX (Ocean Drilling Program).

2 Lamont-Doherty Geological Observatory of Columbia University, Palisades, NY 10964, U.S.A.

${ }^{3}$ Graduate School of Oceanography, University of Rhode Island, Narragansett, RI 02882, U.S.A.
}

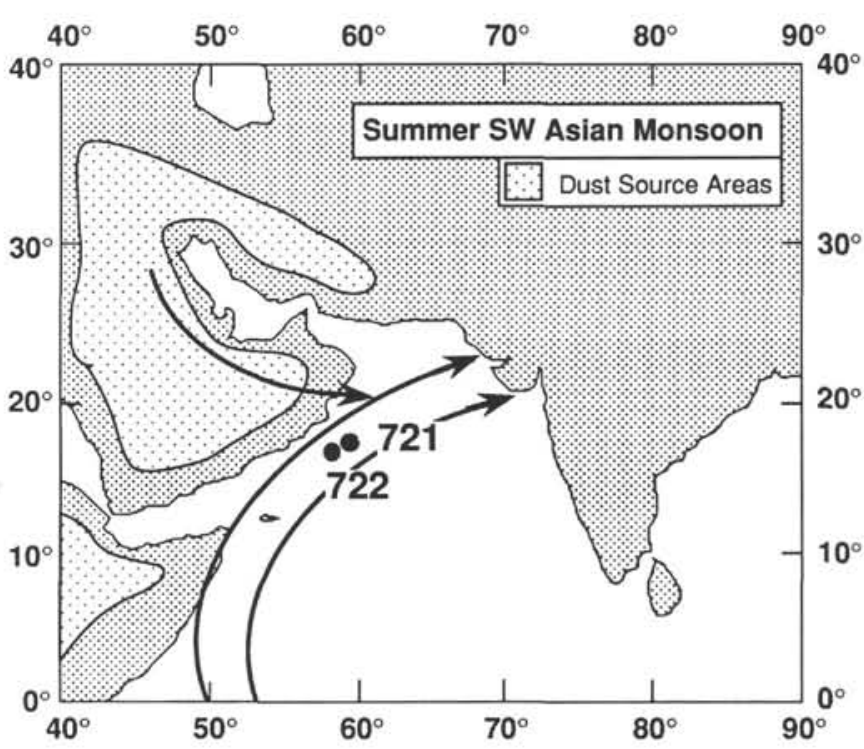

Figure 1. Lower tropospheric (1-2 km altitude) wind fields over the Arabian Sea during the summer monsoon (after Hastenrath and Lamb, 1980). Eolian dust source areas are based on satellite imagery from Sirocko and Sarnthein (1989).

Asian region from October to April, and coastal upwelling is reduced in the Arabian Sea (Fig. 1; Hastenrath, 1985).

The results of several studies have emphasized the importance of summer monsoon eolian dust deposition to the surface sediment composition in the western Arabian Sea (Sirocko and Sarnthein, 1989; Stewart et al., 1965; Goldberg and Griffin, 1970; Kolla and Biscaye, 1977; Kolla et al., 1981). Atmospheric haze frequency data, aerosol, and ocean sediment trap studies 
have demonstrated that most dust transport occurs during the peak months of the summer monsoon: June, July, and August (Pye, 1987, p. 76; Chester et al., 1985; Prospero, 1981; Nair et al., 1989). In particular, the sediment trap data indicate that $80 \%$ of the annual supply of terrigenous material to the western Arabian Sea occurs during these months (Nair et al., 1989).

Satellite imagery (Sirocko and Sarnthein, 1989) and analyses of pollen and mineral aerosols (Van Campo, 1983; Van Campo et al., 1982; Kolla et al., 1976, 1981; Goldberg and Griffin, 1970; Sirocko and Sarnthein, 1989) have shown that the dust entrained during the summer monsoon originates in arid Somali and Arabian Peninsula source regions. Transport vectors are southwest from Somali sources and northwest from Arabian sources; the northwest vector over Arabia provides the most significant supply of dust to the Arabian Sea (Fig. 1). Analyses of wind field charts indicate that the transporting wind flow takes place in the mid-troposphere at 1-2 km (Goldberg and Griffin, 1970; Sirocko and Sarnthein, 1989).

While the Indus River is the dominant source of sediment to the northern and eastern Indian Ocean basins, core studies suggest that it is not a significant source of terrigenous sediment to the western Arabian Sea, largely because the Owen Ridge acts as an effective barrier to these sediments (Goldberg and Griffin, 1970; Clemens and Prell, in press).

\section{Late Pleistocene Variability of the Summer Monsoon}

The sensitivity of the Asian monsoon to seasonal insolation variations is also expressed over geological time scales $\left(10^{4}-10^{5}\right.$ years), where variations in earth orbital geometry give rise to periodic variations in the seasonal distribution of insolation (Berger, 1978). The effects of these orbital insolation variations on the intensity of the summer monsoon has been studied from both paleoclimatic and general circulation model (GCM) perspectives (Singh et al., 1972; McClure, 1976; Kutzbach, 1981; Van Campo et al., 1982; Swain et al., 1983; Prell, 1984; StreetPerrott and Harrison, 1984; Pokras and Mix, 1985; Prell and Van Campo, 1986; Clemens and Prell, in press).

In summarizing the paleoclimate and GCM data, Prell and Kutzbach (1987) note that paleoclimatic indices of summer monsoon intensity (Arabian Sea upwelling, windborne pollen, terrigenous grain size, Arabian and west Indian precipitation, north African lake levels) are at maximum values when perihelion (closest pass to the Sun) coincides with summer solstice (longest summer day), providing maximum summer season insolation in the Northern Hemisphere (precessional minima, e.g., is 11 k.y. B.P.). Conversely, the summer monsoon is weak when summer season insolation is low (e.g., 21 k.y. B.P., when perihelion occurs during winter). More importantly, the modeling and paleoclimate results suggest that the monsoon responds approximately linearly to precessional insolation variations (Pokras and Mix, 1985; Prell and van Campo, 1986; Prell and Kutzbach, 1987; Clemens and Prell, in press).

Sites $721\left(16^{\circ} 40.6^{\prime} \mathrm{N}, 59^{\circ} 51.9^{\prime} \mathrm{E} ; 1945 \mathrm{~m}\right)$ and $722\left(16^{\circ} 37.3^{\prime} \mathrm{N}\right.$, $59^{\circ} 47.8^{\prime} \mathrm{E} ; 2028 \mathrm{~m}$ ) were drilled near the crest of the Owen Ridge, which is a northeast-southwest trending asymmetric ridge in the Arabian Sea rising $2000 \mathrm{~m}$ above the surrounding bathymetry (Fig. 2). These sites are located approximately $350 \mathrm{~km}$ east of the Arabian Peninsula and are separated by about 9.5 km. Drilling at Site 721 consisted of three offset holes; Site 722 consisted of two offset holes. The sites are well above the modern lysocline. Because of the ridge setting of Sites 721 and 722 and because of the abundant supply of eolian detritus to this region, the record of terrigenous sedimentation at these sites should reflect variations in eolian supply from the monsoon. Detailed terrigenous accumulation and grain-size analyses of piston cores from this region have confirmed that terrigenous sedimentation is dominated by variations in eolian supply for the last 400 k.y. (Clemens and Prell, in press).

The objectives of this study are: (1) to present a detailed record of late Neogene (0-3.2 Ma) variations in terrigenous (eolian) sedimentation at Sites 721 and 722 , and (2) to discuss the significance of these data in the context of general global climate evolution during this interval. The terrigenous fraction variations are derived from very high resolution $(5 \mathrm{~cm} ; 1.0-1.5$ k.y.) measurements of whole-core magnetic susceptibility using a combined magnetic-sedimentologic approach. We use these data to evaluate the possible influence of high-latitude climate processes on low-latitude dust source regions and the climate of the Asian monsoon.

The late Neogene is punctuated by several climatic shifts that mark a general cooling trend in global climate. Northern Hemisphere ice sheets expanded rapidly near $2.4 \mathrm{Ma}$ (Shackleton et al. 1984). Between 2.4 and $0.7 \mathrm{Ma}$ ice volume variations were relatively low in amplitude and varied predominantly at 41 k.y. (Raymo et al., 1989). After 0.7 Ma the amplitude of ice volume variations increased considerably and the dominant periodicity shifted to 100 k.y. (Ruddiman et al., 1989). Here we focus on a shift in the mode of terrigenous (eolian) deposition that occurs at $2.4 \mathrm{Ma}$ and may reflect changes in climate in the dust source area as a result of rapid expansion of Northern Hemisphere ice sheets at this time.

\section{Magnetic Susceptibility}

Magnetic susceptibility is a measure of the concentration of magnetic material in a sample. It is not a remanence measurement; it is determined by the ratio of induced magnetization to an applied field and reflects the integrated contribution of all magnetic constituents. Since the terrigenous fraction of most deep-sea sediments contains trace amounts (typically $<0.01 \%$ ) of strongly ferrimagnetic minerals (magnetite), downcore variations in magnetic susceptibility are usually monitoring variations in terrigenous concentration. Detrital magnetic minerals such as magnetite (strongly ferrimagnetic) and goethite and hematite (antiferromagnetic) are the most common magnetic constituents of the lithogenic fraction in deep-sea carbonate sediments (Lowrie and Heller, 1982). Because of their very low specific susceptibilities, contributions from paramagnetic clays and diamagnetic calcite and opal are usually a negligible component of the measured susceptibility. Provided that susceptibility is shown to be a conservative indicator of the terrigenous fraction, its link to paleoclimate is through the climatically controlled variations in the supply of terrigenous and biogenic components (Kent, 1982; Robinson, 1986). It is this link between climate and sediment magnetism that will be investigated here.

Various applications of magnetic methods to paleoclimatic problems have been presented in previous studies (Thompson et al., 1980; Bloemendal, 1983; Mead et al., 1986; Robinson, 1986; Bloemendal et al., 1988; Doh et al., 1988; deMenocal et al., 1988; Bloemendal and deMenocal, 1989). The main advantage of these techniques is that they are orders of magnitude faster than other methods of determining terrigenous fraction variations. Procedures for isolating the terrigenous fraction typically require an average of about $1-2 \mathrm{hr}$ per sample (e.g., Rea and Janecek, 1981); susceptibility measurements take $10 \mathrm{~s}$. Discrete samples are not required and whole-unsplit core sections can be measured continuously using a pass-through loop sensor.

The principal factor that restricts the use of susceptibility as an indicator of terrigenous fraction variations is sediment diagenesis. Reductive and oxidative diagenesis affects the redox stability of iron-bearing minerals, and the resulting changes in magnetic properties can decouple any potential relationship between susceptibility and terrigenous percent (Kent and Lowrie, 


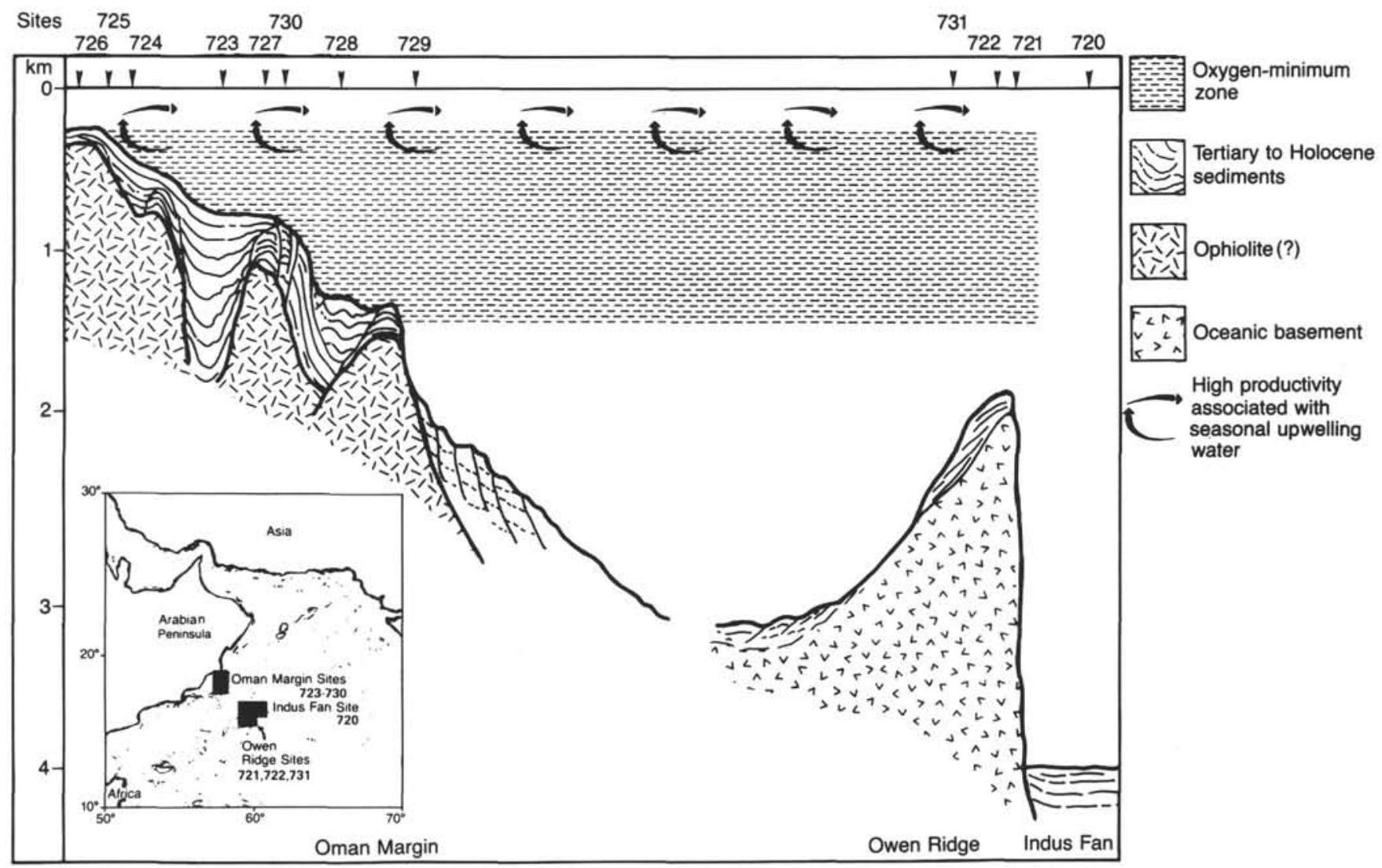

Figure 2. Locations of Sites 721 and 722 on the Owen Ridge in the western Arabian Sea.

1974; Froelich et al., 1979; Henshaw and Merrill, 1980; Karlin and Levi, 1983; Canfield and Berner, 1987). An additional factor that limits the use of susceptibility as a conservative indicator of terrigenous percent is the possibility of multiple terrigenous sediment sources. If there are two or more sources of terrigenous sediment with widely different susceptibilities, the measured susceptibility of the bulk sediment will no longer be a conservative indicator of terrigenous fraction variations. These potential problems are considered in the present study.

\section{ANALYTICAL METHODS}

Volume magnetic susceptibility was measured at 5-cm intervals on unsplit whole-core sections of Holes 721A, 721B, 721C, $722 \mathrm{~A}$, and 722B using a Bartington Instruments' MSC2 passthrough loop sensor $(0.47 \mathrm{kHz}, 0.01 \mathrm{mT} \mathrm{AF})$ during the actual occupancy of the site. Instrument sensitivity is of the order of $10^{-7} \mathrm{SI}$ units and measurements were calibrated using a paramagnetic $\mathrm{MnO}_{2}$ standard. The measurement interval is equivalent to about $1.2 \mathrm{k} . \mathrm{y}$. based on an average sedimentation rate of $3.5 \mathrm{~cm} \mathrm{k.y.}{ }^{-1}$. At each of the five holes, data quality was best for the uppermost $10-11$ cores $(\sim 100 \mathrm{~m})$, which were recovered using the advanced piston corer (APC). Core recovery below this employed the extended core barrel (XCB), which tended to introduce pipe rust contamination and core disturbance, both of which compromised the quality of the susceptibility data.

To investigate the sedimentological associations of the susceptibility variations, $\sim 10-\mathrm{cm}^{3}$ samples were taken between 0 and 90.0 mbsf of Hole $721 \mathrm{C}$ at levels of susceptibility peaks and troughs at an average sample interval of $\sim 40 \mathrm{~cm}$. The raw bulk samples $(n=172)$ were freeze-dried, gently disaggregated, and mounted for X-ray diffraction (XRD) analysis to assess the gross mineralogical variations associated with the susceptibility data. The dominant mineral assemblage consisted of varying proportions of calcite, quartz, and dolomite and minor plagioclase. The relative abundance of each mineral was estimated by numerically integrating the representative peak area.

The residual sample material was used for terrigenous extractions. The rationale for performing the time-consuming terrigenous extractions is that it is the best, most direct way to assess the fidelity of magnetic susceptibility as a conservative tracer of the terrigenous fraction. The procedure employed is similar to that developed by Rea and Janecek (1981), with some modifications to account for the relatively higher carbonate levels of the Arabian Sea sediments (Clemens and Prell, in press). Ninetyfour samples from 61.0 to $90.0 \mathrm{mbsf}$ in Hole $721 \mathrm{C}$ were selected (late Pliocene to early Pleistocene). The freeze-dried samples were weighed $(6-10 \mathrm{~g})$ and then placed into flasks with $125 \mathrm{ml}$ buffered acetic acid ( $\mathrm{pH} \mathrm{4.5)}$ and shaken for $2 \mathrm{hr}$; this was performed twice (or more, as necessary) to insure complete carbonate removal. Organic carbon removal was achieved using $45 \mathrm{ml}$ of $\mathrm{Na}$ hypochlorite buffered to $\mathrm{pH} 9.5$; this step was performed three times. The sample was then sieved at $63 \mu \mathrm{m}$ to remove large siliceous microfossils; residual opal in the fraction less than $63 \mu \mathrm{m}$ was removed by twice boiling the sample in $300 \mathrm{ml}$ of distilled deionized water (DDW) with $20 \mathrm{~g} \mathrm{NaCO}_{3}$. The samples were washed twice with DDW after each extraction step. The residual sample was then freeze-dried and the terrigenous percentage of initial sample weight was calculated (typically $10 \%-45 \%$ ).

\section{RESULTS}

\section{Interhole Correlations and Composite Sequences}

The results of this study are based on more than 15,000 susceptibility measurements from the uppermost 120 mbsf of Holes $721 \mathrm{~A}, 721 \mathrm{~B}, 721 \mathrm{C}, 722 \mathrm{~A}$, and 722B. The problem of core dis- 
turbance and missing sections at core breaks (Ruddiman et al., 1986; Bloemendal et al., 1988) was circumvented by using the susceptibility data to establish correlative intervals between adjacent holes. Although recovery was excellent, comparison of the susceptibility data between two adjacent holes indicated that between 20 and $100 \mathrm{~cm}$ were typically missing at core breaks (Fig. 3).

The susceptibility records of Sites 721 and 722 are represented by data primarily from Holes $721 \mathrm{~B}$ and $722 \mathrm{~B}$, respectively. Disturbed or missing intervals were "patched" in from adjacent holes; the intervals used to construct the composite sequences at each site are listed in Table 1. Correlations are accurate to within the measurement interval, or $\pm 5 \mathrm{~cm}$. A program was written to recalculate sub-bottom depths based on the additive patching scheme (sub-bottom depths are shifted to accommodate sediment not recovered at core breaks). The new subbottom depths of the composite sequences are also listed in $\mathrm{Ta}-$ ble 1 .

A consequence of the patching procedure is that the final composite depth is $\sim 7 \%$ greater than the equivalent Ocean Drilling Program (ODP) drilling depth. The susceptibility data demonstrate that whereas the APC is apparently recovering all (or more than) $9.7 \mathrm{~m}$ of sediment penetrated during the coring stroke (i.e., $100 \%$ recovery), these cores are not entirely complete when they are measured on the ship and compared to adjacent holes. Each of the four cores shown in Figure 3 had reported recoveries greater than $103 \%$, yet it is clear that sediment is still missing at the core breaks. The fact that core recovery is often greater than $100 \%$ suggests that the missing section at core breaks may be related to core expansion and partial extrusion during the transit from depth to the rig floor.

The "patched" composite susceptibility records for Sites 721 and 722 are shown in Figure 4. The composite sequence of Site 721 extends to 111.95 mbsf composite depth (3.2 Ma); the Site 722 composite sequence extends to $96.55 \mathrm{mbsf}$ composite depth $(\sim 3.0 \mathrm{Ma})$. (Depths referred to hereinafter are composite depths unless otherwise specified.) The most striking feature of this figure is that the two records are essentially identical over their common depth range. Although the two sites are separated by $\sim 8 \mathrm{~km}$ they are correlative in detail. Using the nonlinear signal correlation program of Martinson et al. (1984), the two composite records can be correlated to achieve a final coherency of $0.96(n=1932)$; the plot of Site 722 correlated to Site 721 depths is shown as the center profile in Figure 4 . The similarity of the two records implies that they represent complete stratigraphic sections with no local hiatuses or sediment redistribution.

\section{Susceptibility and Bulk Mineralogy}

The results of the bulk sample XRD analyses are shown in Figures $5 \mathrm{~A}$ and $5 \mathrm{~B}$. Strong correlations exist between susceptibility and quartz $(r=0.83)$ and dolomite $(r=0.70)$. Aerosol studies have shown that these minerals are common constituents of summer monsoon dust (Stewart et al., 1965; Goldberg and Griffin, 1970; Nair et al., 1989; Sirocko and Sarnthein, 1989). These close mineralogical associations suggest that the susceptibility variations are tracking variations in the terrigenous (eolian) fraction. In terms of identifying the dust source regions, clay mineralogy and pollen studies suggest that Arabia and northeast Africa are the most probable dust source areas for the summer monsoon winds (Van Campo, 1983; Van Campo et al., 1982; Kolla et al., 1976, 1981; Goldberg and Griffin, 1970; Sirocko and Sarnthein, 1989).

\section{Origin of the Susceptibility Variations}

The correlation between the terrigenous fraction and susceptibility is shown in Figure 6; the strikingly good correlation $(r=$
0.98 ) has several implications. The single most important result is that susceptibility is a conservative indicator of terrigenous fraction variations. The uppermost 5-7 $\mathrm{m}$ of Sites 721 and 722 shows sharp decreases in susceptibility that are not paralleled by proportional decreases in terrigenous percent (see Clemens and Prell, this volume). This may be indicative of some reductive diagenesis. But the extremely close correlation between susceptibility and terrigenous percent indicates that time-dependent variations in diagenesis are not influencing this correlation. Rather, the surface decrease in susceptibility and the generally unstable paleomagnetic results from these sites suggest that only the finest magnetic grains are experiencing significant diagenesis (e.g., reduction to pyrite) and empirical studies have demonstrated that diagenesis is biased toward the finest grains (Canfield and Berner, 1987). Rock magnetic measurements on samples from nearby piston cores demonstrate that anhysteretic remanence (ARM) values decrease to negligible values within the uppermost 2-3 mbsf, suggesting that fine, single-domain (SD) grains have experienced diagenesis to weakly ferrimagnetic or paramagnetic iron sulfides.

We have performed some preliminary rock magnetic measurements to estimate magnetic mineralogy and grain size. For eight samples taken from Hole 721C (55.75-57.95 mbsf), coercivity of remanence values were $30 \mathrm{mT}$ and Curie temperatures were $580^{\circ} \mathrm{C}$, indicating that the magnetic carrier is relatively coarse-grained, multidomain magnetite ( $>16 \mu \mathrm{m}$; based on pseudo-single domain to multidomain transition size for magnetite; Dunlop, 1973). Remanence saturation values indicate that the range of magnetite concentrations is $\sim 0.01-0.02 \%$ by weight of the terrigenous fraction (e.g., Thompson and Oldfield, 1986, p. 23).

Using the regression equation shown in Figure 6, the susceptibility of the Arabian Sea sediments at zero terrigenous percent is $-11 \mu \mathrm{SI}$. This value is very close to the volume diamagnetic susceptibility of calcite (-13 $\mu \mathrm{SI}$; see Thompson and Oldfield, 1986), which suggests that there is no background supply of magnetic material to this region. That is, the negative intercept value indicates that there is no significant source of magnetic material other than that associated with the terrigenous fraction. With regard to multiple sources of terrigenous sediment, the very strong correlation in Figure 6 suggests that there is one dominant (eolian) source of terrigenous sediment to the site. It is possible, but unlikely, that there may be multiple sources with identical magnetic mineral concentrations. If there were multiple terrigenous sources with significantly different magnetic mineral concentrations, the susceptibility-terrigenous percent plot would not have the distinctly linear character apparent in Figure 6.

\section{DISCUSSION}

\section{The Time-Series}

Age control for the Site 721 composite sequence was provided by bio- and magnetostratigraphic datums that were determined for Holes 721A, 721B, and 722A. The datums were transferred from each hole to the appropriate depth in the Site 721 composite sequence using the susceptibility correlations. The ability to correlate between holes to within $\pm 5 \mathrm{~cm}$ accuracy allows the datums from the three holes to be compiled and compared on one composite depth scale. An example of this is shown in Figure 3 where the positions of the Matuyama-Gauss Chronozone boundary at Holes 721A, 721B, 722A, and 722B are depicted by vertical bars adjacent to the Site 721 composite sequence. These four datums can be reconciled if the Matuyama-Gauss boundary is placed at $88.30 \mathrm{mbsf}$; this datum (2.47 Ma) was used in the age model. A total of 46 datums was used to constrain the preliminary age model shown in Figure 7 (Table 2). 


\section{Susceptibility correlations at Site 721}
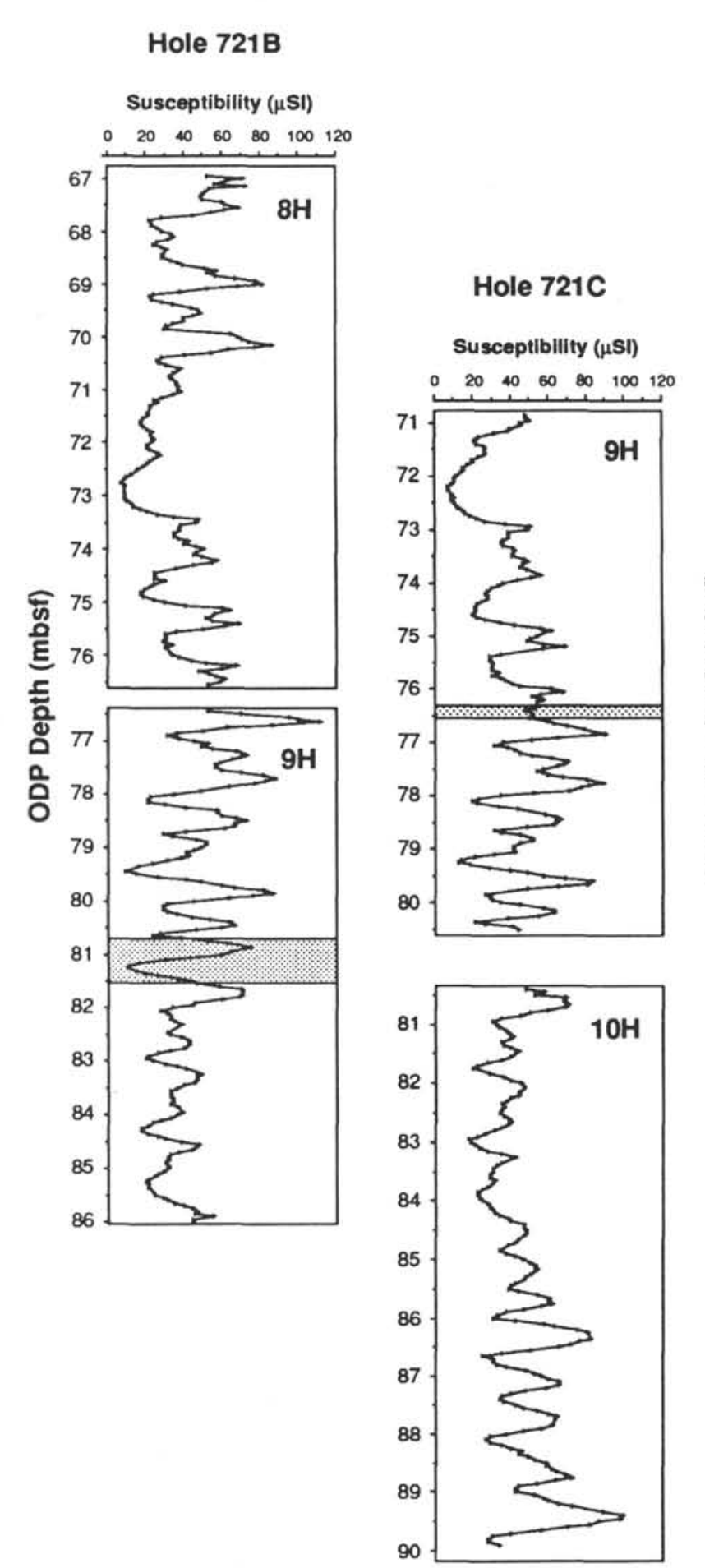

Site 721

Composite

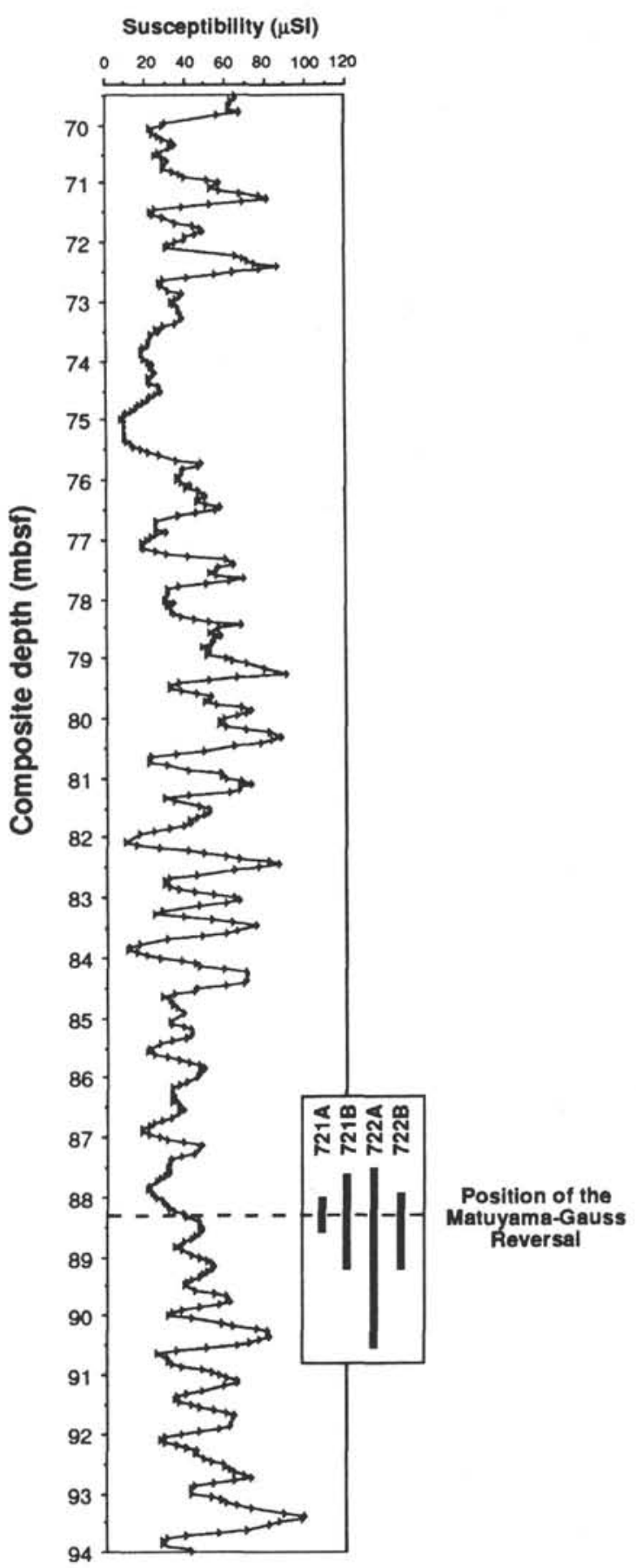

Figure 3. Interhole correlations using the magnetic susceptibility data. The shaded areas represent the missing section between core breaks; these were used to construct a complete composite sequence, a portion of which is shown to the right of the figure. The susceptibility data were also used to constrain the position of the Matuyama-Gauss Chronozone boundary ( $2.47 \mathrm{Ma} ; 88.30 \mathrm{mbsf}$ composite depth) based on data from Holes 721A, 721B, 722A, and 722B. 
Table 1. Construction of composite sequences for Sites 721 and $722 .^{\mathrm{a}}$

\begin{tabular}{|c|c|c|c|c|c|c|c|}
\hline \multicolumn{4}{|c|}{ Site 721} & \multicolumn{4}{|c|}{ Site 722} \\
\hline Hole & Start read & End read & $\begin{array}{l}\text { Composite } \\
\text { depth } \\
\text { interval }(m)\end{array}$ & Hole & Start read & End read & $\begin{array}{l}\text { Composite } \\
\text { depth } \\
\text { interval (m) }\end{array}$ \\
\hline $721 \mathrm{~B}$ & $1 \mathrm{H}-1,15$ & $1 \mathrm{H}-6,100$ & $0.15-8.50$ & $722 B$ & $1 \mathrm{H}-1,5$ & $1 \mathrm{H}-4,50$ & $0.05-5.00$ \\
\hline $721 \mathrm{C}$ & $2 \mathrm{H}-4,20$ & $2 \mathrm{H}-6,115$ & $8.55-10.20$ & $722 \mathrm{~A}$ & $1 \mathrm{H}-3,55$ & $1 \mathrm{H}-4,55$ & $5.05-6.55$ \\
\hline $721 \mathrm{~B}$ & $2 \mathrm{H}-1,105$ & $2 \mathrm{H}-6,115$ & $10.25-17.95$ & $722 B$ & $2 \mathrm{H}-1,90$ & $2 \mathrm{H}-6,45$ & $6.60-13.65$ \\
\hline $721 \mathrm{C}$ & $3 \mathrm{H}-3,105$ & $3 \mathrm{H}-5,125$ & $18.00-21.20$ & $722 \mathrm{~A}$ & $2 \mathrm{H}-2,100$ & $2 \mathrm{H}-4,35$ & $13.70-16.05$ \\
\hline $721 \mathrm{~B}$ & $3 \mathrm{H}-2,20$ & $3 \mathrm{H}-6,80$ & $21.25-27.85$ & $722 B$ & $3 \mathrm{H}-1,35$ & $3 \mathrm{H}-7,30$ & $16.10-25.05$ \\
\hline $721 \mathrm{~A}$ & $3 \mathrm{H}-4,65$ & $3 \mathrm{H}-6,105$ & $27.90-31.30$ & $722 \mathrm{~A}$ & $3 \mathrm{H}-3,100$ & $3 \mathrm{H}-4,95$ & $25.10-26.55$ \\
\hline $721 \mathrm{~B}$ & $4 \mathrm{H}-2,40$ & $4 \mathrm{H}-6,90$ & $31.35-37.85$ & $722 B$ & $4 \mathrm{H}-1,60$ & $4 \mathrm{H}-6,90$ & $26.60-34.40$ \\
\hline $721 \mathrm{C}$ & $5 \mathrm{H}-3,115$ & $5 \mathrm{H}-5,25$ & $37.90-40.00$ & $722 \mathrm{~A}$ & $4 \mathrm{H}-3,15$ & $4 \mathrm{H}-4,55$ & $34.45-36.35$ \\
\hline $721 \mathrm{~B}$ & $5 \mathrm{H}-1,40$ & $5 \mathrm{H}-7,35$ & $40.05-49.00$ & $722 \mathrm{~B}$ & $5 \mathrm{H}-1,65$ & $5 \mathrm{H}-7,20$ & $36.40-44.95$ \\
\hline $721 \mathrm{C}$ & $6 \mathrm{H}-4,85$ & $6 \mathrm{H}-5,100$ & $49.05-50.70$ & $722 \mathrm{~A}$ & $5 \mathrm{H}-3,75$ & $5 \mathrm{H}-4,145$ & $45.00-47.20$ \\
\hline $721 \mathrm{~B}$ & $6 \mathrm{H}-1,90$ & $6 \mathrm{H}-7,20$ & $50.75-59.05$ & $722 \mathrm{~B}$ & $6 \mathrm{H}-1,130$ & $6 \mathrm{H}-7,15$ & $47.25-55.10$ \\
\hline $721 \mathrm{C}$ & $7 \mathrm{H}-4,90$ & $7 \mathrm{H}-5,40$ & $59.10-60.10$ & $722 \mathrm{~A}$ & $6 \mathrm{H}-3,70$ & $6 \mathrm{H}-5,10$ & $55.15-57.55$ \\
\hline $721 \mathrm{~B}$ & $7 \mathrm{H}-1,85$ & $7 \mathrm{H}-7,10$ & $60.15-68.40$ & $722 \mathrm{~B}$ & $7 \mathrm{H}-1,95$ & $7 \mathrm{H}-7,30$ & $57.60-65.95$ \\
\hline $721 \mathrm{C}$ & $8 \mathrm{H}-4,5$ & $8 \mathrm{H}-5,5$ & $68.45-69.95$ & $722 \mathrm{~A}$ & $7 \mathrm{H}-3,115$ & $7 \mathrm{H}-4,90$ & $66.00-67.25$ \\
\hline $721 \mathrm{~B}$ & $8 \mathrm{H}-1,85$ & $8 \mathrm{H}-7,30$ & $70.00-78.45$ & $722 \mathrm{~B}$ & $8 \mathrm{H}-1,50$ & $8 \mathrm{H}-7,15$ & $67.30-75.95$ \\
\hline $721 \mathrm{C}$ & $9 \mathrm{H}-4,80$ & $9 \mathrm{H}-5,25$ & $78.50-79.45$ & $722 \mathrm{~A}$ & $8 \mathrm{H}-3,75$ & $8 \mathrm{H}-4,75$ & $76.00-77.50$ \\
\hline $721 \mathrm{~B}$ & $9 \mathrm{H}-1,50$ & $9 \mathrm{H}-6,135$ & $79.50-87.85$ & $722 \mathrm{~B}$ & $9 \mathrm{H}-1,35$ & $9 \mathrm{H}-7,60$ & $77.55-86.80$ \\
\hline $721 \mathrm{C}$ & $10 \mathrm{H}-3,60$ & $10 \mathrm{H}-7,55$ & $87.90-93.85$ & $722 \mathrm{~A}$ & $9 \mathrm{H}-3,110$ & $9 \mathrm{H}-4,105$ & $86.85-88.30$ \\
\hline $721 \mathrm{~B}$ & $10 \times-4,15$ & $10 X-6,65$ & $93.90-97.40$ & $722 B$ & $10 \mathrm{H}-1,35$ & $10 \mathrm{H}-6,105$ & $88.35-96.55$ \\
\hline $721 \mathrm{C}$ & $11 X-3,35$ & $11 \mathrm{X}-\mathrm{CC}, 30$ & $97.45-101.34$ & & & & \\
\hline $721 C^{b}$ & $12 \times 01,5$ & $12 \times 05,135$ & $101.39-108.69$ & & & & \\
\hline $722 \mathrm{~A}$ & $11 \times 04,90$ & $11 \times 06,110$ & $108.74-111.94$ & & & & \\
\hline
\end{tabular}

${ }^{\text {a }}$ Correlations are based on magnetic susceptibility data and are accurate to within one measurement inter-

val $( \pm 5 \mathrm{~cm})$. The "Start read" and "End read" depths are inclusive.

${ }^{b}$ Correlation not possible between Core $721 \mathrm{C}-11 \mathrm{X}$ and Core $721 \mathrm{C}-12 \mathrm{X}$.

A detailed oxygen isotopic stratigraphy has been established to $1 \mathrm{Ma}$ for Hole 722B (Clemens and Prell, this volume) and these datums were transferred using susceptibility correlations to the Site 721 composite sequence. The basal age of the composite sequence is $3.2 \mathrm{Ma}$. The mean sedimentation rate for the entire sequence is $3.5 \mathrm{~cm} \mathrm{k.y.}{ }^{-1}$, so the $5-\mathrm{cm}$ measurement interval is roughly equivalent to $\sim 1.2 \mathrm{k} . \mathrm{y}$. The age model presented in Figure 7 represents an effort to include as many datums as possible within a series of straight line segments. The susceptibility time-series based on this age model is shown in Figure 8.

The power spectra (shown as log variance with $95 \%$ confidence interval and bandwidth bars) of the entire 3.2 Ma susceptibility record were calculated using standard methods (Imbrie et al., 1984) and the results are shown in Figure 9. The uppermost 180 k.y. $(\sim 8 \mathrm{~m})$ of the record was excluded from this calculation. These data demonstrate that much of the variance in the record occurs at the 41 k.y. and 23-19 k.y. orbital periodicities. Variance peaks at non-orbital periodicities (e.g., 0.076 k.y. ${ }^{-1}$ or 13 k.y.) apparently reflect minor inadequacies of the age model between 1.6-1.0 Ma which may be resolved once an isotopic stratigraphy is developed for the entire record. Power spectra were also calculated for four discrete intervals of the 3.2 Ma record. The results (shown as scaled variance) are plotted above each appropriate segment in Figure 7. These results demonstrate an important feature of the susceptibility time-series; although variance is concentrated at orbital periodicities throughout the $3.2 \mathrm{Ma}$ record, there is a non-stationarity (frequency evolution) of the susceptibility variations that occurs at $\sim 2.5$ $\mathrm{Ma}$. Prior to $\sim 2.5 \mathrm{Ma}$, the susceptibility data vary predominantly at the 23-19 k.y. periodicities corresponding to orbital precession. After this time the record varies predominantly at the $41 \mathrm{k} . \mathrm{y}$. periodicity corresponding to orbital obliquity.

\section{Late Pliocene (3.2-1.6 Ma) Evolution of Terrigenous Sedimentation at the Owen Ridge}

We now focus on the frequency-domain characteristics of the susceptibility record from 3.2 to $1.6 \mathrm{Ma}$. There is a change in sedimentation rate that occurs at some point between 1.6 and
1.0 Ma which cannot be resolved in detail based on the datums shown in Figure 7. Since 23-19 k.y. variance is observed throughout the entire 3.2-1.6 Ma portion of the record (Fig. 7), this interval can be filtered at the precessional band to examine the degree of coherency between the susceptibility record and orbital precession.

Precession is characterized by 400 k.y. and 100 k.y. modulation "envelopes" of the 23-19 k.y. cycles; these envelopes should also be apparent in the filtered susceptibility record if orbital insolation variations are responsible for the observed variations. The accuracy and frequency stability of the precessional index $(-e \sin (\omega))$ has been investigated (Berger, 1984; Berger and Pestiaux, 1984), and the most recent solutions indicate that the position in time of a given precessional cycle is accurate to within one wavelength ( $\sim 22 \mathrm{k}$.y.) to $\sim 1.5 \mathrm{Ma}$. The enveloped character of precession, however, is tied to orbital eccentricity and does not deteriorate (is stable) over the 5.0-Ma interval for which the solutions have been calculated (Berger, 1984).

The data were band-pass filtered at $25-19$ k.y. ( 22 k.y., 0.045 k.y. ${ }^{-1}$ central frequency) to extract the precessional component of variation. To examine the degree of coherency between this signal and -esin $(\omega)$, the filtered susceptibility record was phaselocked ("tuned") to the precesssional signal using the CORPAC non-linear correlation program (Martinson, 1982; Martinson et al., 1984; Imbrie et al., 1984). The precessional index and the correlated susceptibility data (both filtered and raw) are shown in Figure 10.

Since the original age model is only approximate, the phaselocking procedure performs minor age-shifting adjustments and acts to align the signals and to maximize their correlation. The "tuned" age model is superimposed upon the original age model in Figure 11. We emphasize that the original age model datums for this interval were preserved within their age and depth error limits after the tuning procedure. The only significant change from the original age model is a slight inflection at $2.12 \mathrm{Ma}$ (Fig. 11). Although there are no stratigraphic datums of this age to test this pick, we present supporting evidence for it in the following paragraphs. 
Site 721

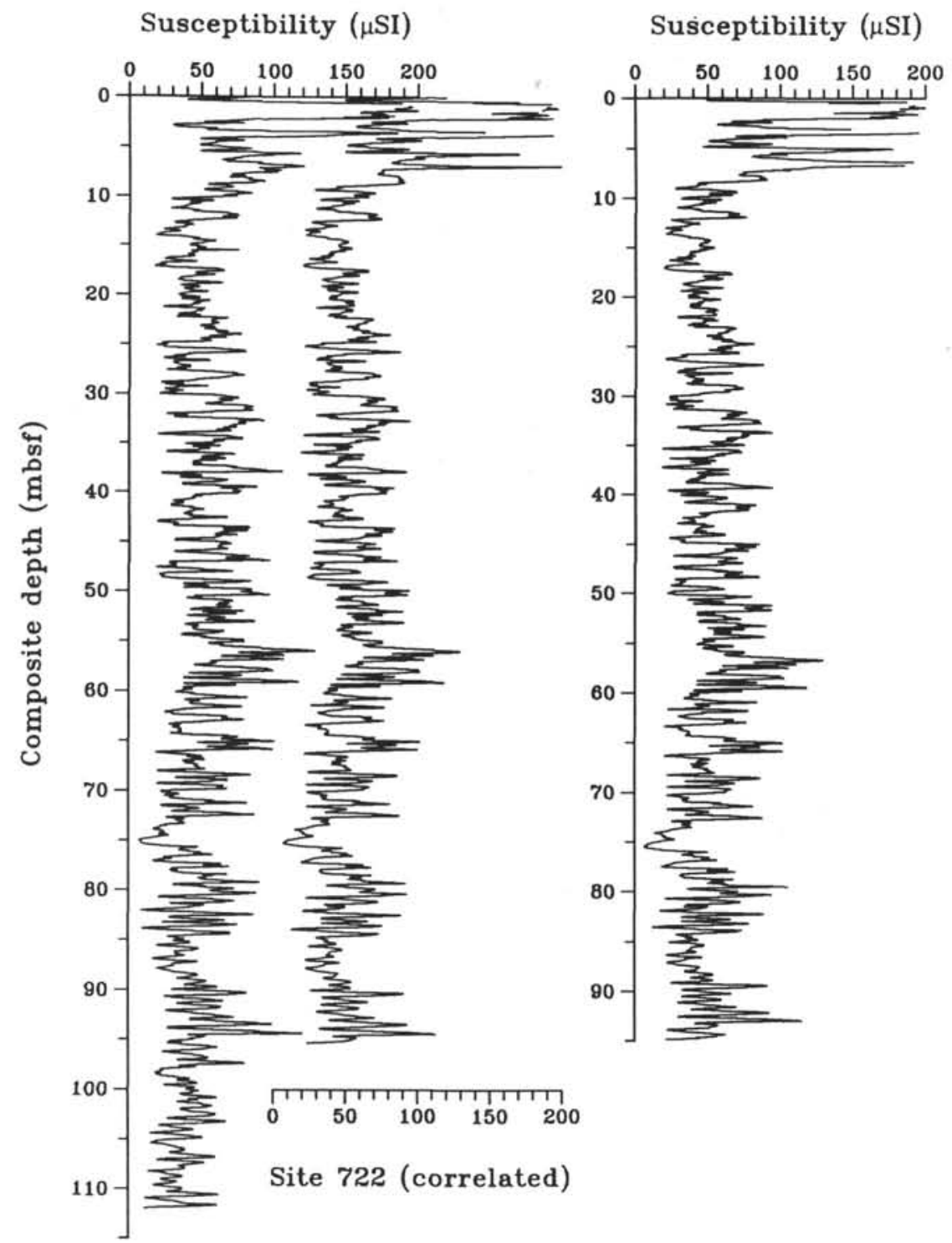

Site 722

Susceptibility $(\mu \mathrm{SI})$

Figure 4. Depth plots of the composite magnetic susceptibility records from Sites 721 and 722. The middle curve is the Site 722 susceptibility record correlated to the Site 721 record using the inverse correlation program of Martinson et al. (1984). The coherency between the correlated Site 722 data and Site 721 is high (0.95).

The coherency between the precession index and the "tuned" filtered susceptibility over the entire $3.2-1.6 \mathrm{Ma}$ interval is 0.86 . Coherency is highest between 3.2 and $2.5 \mathrm{Ma}(0.89)$, and it is lower from 2.5 to $1.6 \mathrm{Ma}(0.83)$. The filtered record clearly reflects the modulated character of the precessional index curve, and this is reflected by the very high coherencies. These coherency levels are comparable to those reported for many late Pleistocene studies where coherent orbital forcing of climatically sensitive parameters has been demonstrated (e.g. Imbrie et al., 1984; Pokras and Mix, 1985; Prell and Van Campo, 1986). These data represent the oldest paleoclimatic record demonstrating both power and coherency at the precessional band.

Power spectra were calculated for three intervals (3.2-2.5 Ma, 2.5-2.1 Ma, and 2.1-1.6 Ma) to demonstrate the frequency-domain evolution of the susceptibility variations. These results confirm the power spectra based on the original age model (Fig.
7). There is a definite shift in the dominant mode of variation at $\sim 2.5 \mathrm{Ma}$. Between 3.2 and $2.5 \mathrm{Ma}$ the data vary predominantly at $23-19$ k.y. ( $41 \%$ of total variance), and power at 41 k.y. is subordinate $(14 \%)$. After $\sim 2.5 \mathrm{Ma}$ power at the $23-19$ k.y. band remains high ( $39 \%$ of total variance), but there is a dramatic increase in $41 \mathrm{k} . \mathrm{y}$. power $(37 \%)$. Although the tuning procedure focused variance at the precessional band, it also focused variance at the 41 k.y. obliquity band (Fig. 10). Since the increase in power at $41 \mathrm{k} . y$. is a result of tuning at the precessional, not obliquity, band, this supports the implicit assumption of the tuning procedure, namely that orbital insolation-forcing is responsible for the observed climatic response. Furthermore, the well-defined variance peaks at both orbital bands support the tuned age model shown in Figure 11.

To constrain the timing of the increase in $41 \mathrm{k} . \mathrm{y}$. power, the susceptibility time-series (including the 2.12-Ma pick) was sepa- 
A

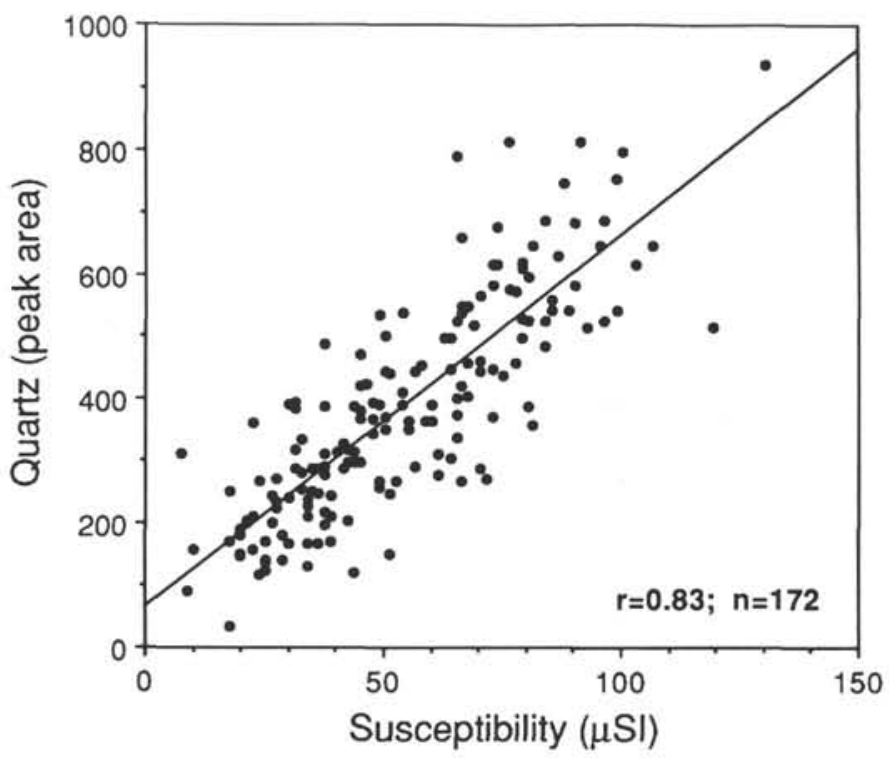

B

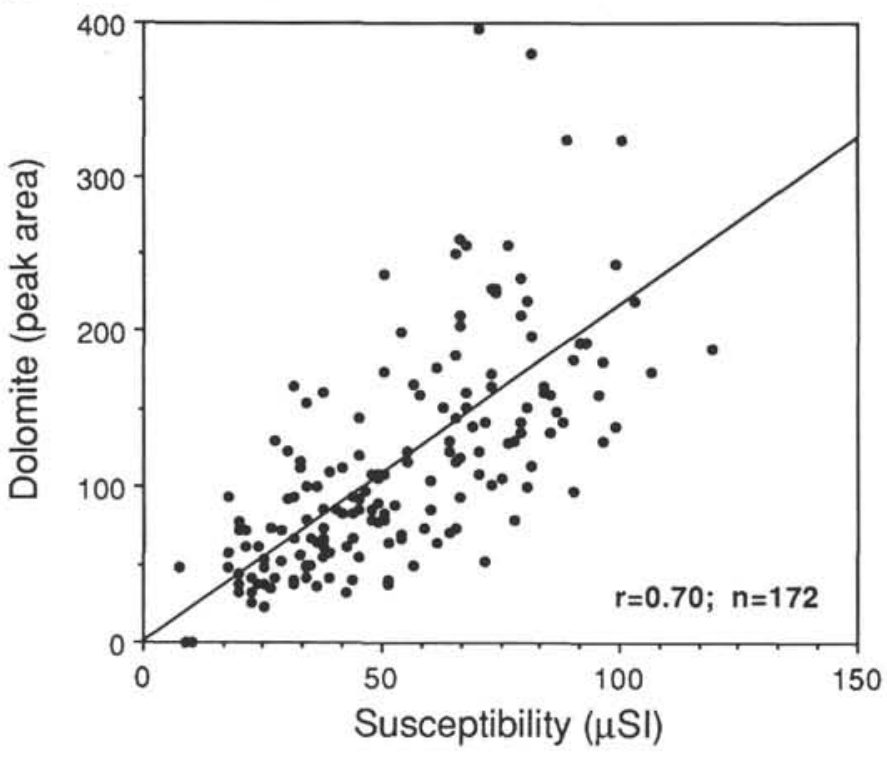

Figure 5. Correlations of bulk X-ray diffraction estimates of quartz (A) and dolomite (B) abundances with magnetic susceptibility. Previous aerosol and sediment studies have identified an eolian origin for these minerals in the Arabian Sea (Stewart et al., 1965; Goldberg and Griffin, 1970; Sirocko and Sarnthein, 1989).

rated into a series of overlapping 400-k.y. "windows," and power spectral estimates were calculated for each "window" (Fig. 12). The results (shown as scaled variance) demonstrate that the shift occurs near $2.4 \mathrm{Ma}$. The first significant increase in $41 \mathrm{k} . \mathrm{y}$. power is seen in the $2.2-2.6 \mathrm{Ma}$ window; power is roughly equally distributed between the $41 \mathrm{k} . \mathrm{y}$. and 23-19 k.y. bands in the 2.0-2.4 Ma window. Inspection of Figure 3 demonstrates that the shift from predominantly $23-19 \mathrm{k}$.y. variance to 41 k.y. variance in the susceptibility record definitely occurs above the Matuyama-Gauss transition (at $2.47 \mathrm{Ma}$ ).

\section{Terrigenous and Biogenic Component Flux Calculations}

Although susceptibility and terrigenous percent have been shown to be closely correlated, the relationship between suscep- tibility and terrigenous accumulation is not known a priori. Using the "tuned" time scale it is possible to extract detailed sedimentation-rate information, which can be used to determine whether the susceptibility variations are dominantly the result of terrigenous influx variations or dilution by biogenic influx variations. We have selected susceptibility data from the $2.75-$ $2.55 \mathrm{Ma}$ interval (see Fig. 10) to address this problem because: (1) the data vary predominantly at the $23-19$ k.y. periodicities over this interval and, (2) the variations are strongly coherent with the precessional index $(-e \sin (\omega))$. Figure 13 shows the precessional index data for $2.75-2.55 \mathrm{Ma}$ and the raw (unfiltered), uncorrelated susceptibility data from Sites 721 and 722 that correspond to this interval. Data from both Sites 721 and 722 were used to demonstrate that the final result is not site-dependent.

The raw data were correlated to the precessional index using the CORPAC correlation package (Martinson et al., 1984). The main assumption implicit in this procedure is that susceptibility (as an eolian proxy indicator) reflects a linear climate response to the precessional insolation forcing. Sedimentation rates for each data point were determined by calculating the first derivative of depth as a function of age for the correlated sequences. Dry bulk densities (DBD) were derived from shipboard GRAPE (Gamma-Ray Attenuation Porosity Evaluator) wet bulk densities (WBD) using the DBD-GRAPE WBD relation determined for the Owen Ridge sediments (Clemens and Prell, this volume). Susceptibility data were converted to terrigenous fraction values using the regression equation shown in Figure 6, and biogenic fraction values were calculated using the one's-complement of the terrigenous fraction data $(1-$ terrigenous percent). The biogenic component is dominantly carbonate since opal is only a few percent in these sediments. The relations used to calculate the terrigenous and biogenic fluxes are

\section{$\mathrm{DBD}=-1.27+1.35$ (GRAPE WBD);}

Terrigenous fraction $=[4.80+0.405$ (susceptibility) $] / 100$; and

Mass accumulation rate $(\mathrm{AR})=\mathrm{DBD} \times$ sedimentation rate; Terrigenous AR $=$ Terrigenous fraction $\times$ Mass AR;

Biogenic $A R=(1-$ Terrigenous fraction $) \times$ Mass AR.

The precessional index, "tuned" susceptibility data, mass $\mathrm{AR}$, terrigenous $\mathrm{AR}$, and biogenic AR data for Sites 721 and 722 are shown in Figure 14. Cross-plots of the fraction and accumulation rate data can be used to demonstrate whether susceptibility is reflecting variations in terrigenous supply or dilution by biogenic supply. For example, if terrigenous supply is diluting the biogenic component, an inverse relation between terrigenous AR and biogenic percent would result. These crossplots are shown in Figures 15A and 15B; the data from both sites indicate that the strongest inverse correlation exists between terrigenous $\mathrm{AR}$ and biogenic percent. Figure $15 \mathrm{C}$ shows this relationship most directly: susceptibility is positively correlated to terrigenous accumulation. These results demonstrate that the susceptibility variations are reflecting terrigenous supply and not dilution by biogenic supply. Detailed analyses of terrigenous and biogenic sedimentation on the Owen Ridge during the late Pleistocene confirm this result (Clemens and Prell, in press, and this volume).

\section{PALEOCLIMATIC ORIGIN OF THE 2.4-Ma SHIFT}

We suggest that the increase in 41 k.y. power in the Arabian Sea susceptibility record after $2.4 \mathrm{Ma}$ reflects the inception of ice-sheet-induced aridity at the Asian monsoon dust source areas. The coincidence of the shift with the rapid expansion of Northern Hemisphere ice sheets and the predominance of 41 


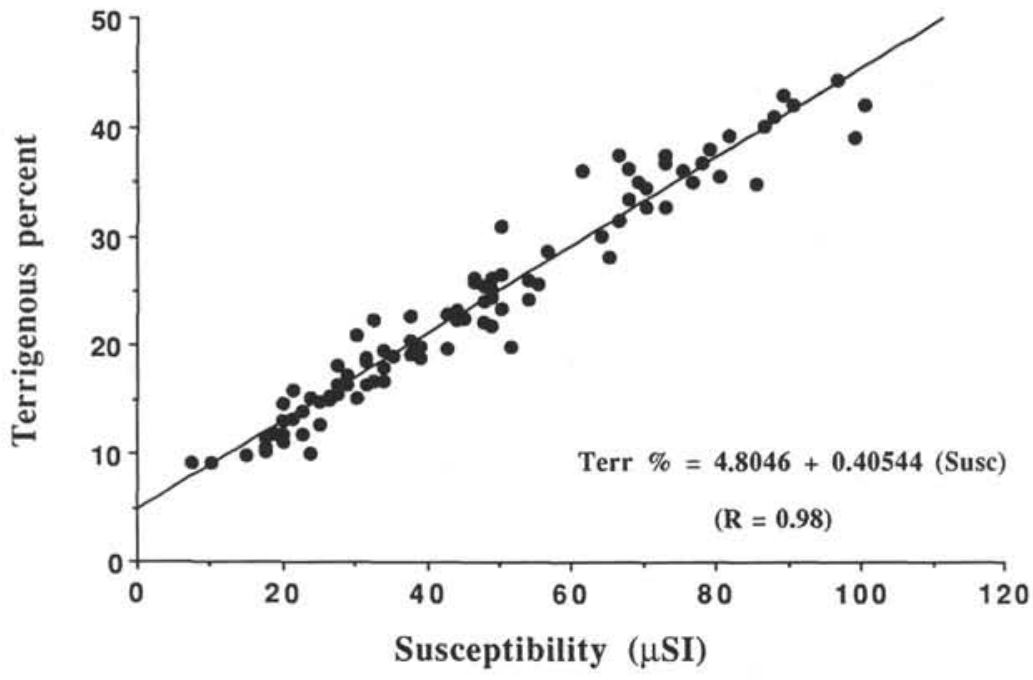

Figure 6. Correlation between terrigenous percent (determined after the sequential extraction of carbonate, opal, and organic carbon) and magnetic susceptibility. The extremely high correlation suggests that susceptibility can be used as a rapid and conservative tracer of the terrigenous fraction variations. The negative $\mathrm{x}$-intercept value indicates that there is no background supply of magnetic material unassociated with the terrigenous fraction.

k.y. power after this time (the dominant periodicity of the marine $\delta^{18} \mathrm{O}$ record) suggest that high-latitude ice sheets may be modulating low-latitude dust source area aridity. The rapid expansion of high-latitude ice sheets at $2.4 \mathrm{Ma}$ has been indicated by an abrupt increase in coarse ice-rafted detritus and foraminiferal $\delta^{18} \mathrm{O}$ values at North Atlantic Site 552 (Shackleton et al., 1984). A more detailed record of the $\delta^{18} \mathrm{O}$ increase at North Atlantic Site 607 (Raymo et al., 1989) has confirmed the timing of this event and suggests that ice sheets expanded to $\sim 50 \%$ of their Last Glacial Maximum (LGM, $18 \mathrm{ka}$ ) volume by $2.37 \mathrm{Ma}$. Pollen evidence from Europe also indicates widespread cooling at this time (Suc, 1984). Raymo et al. (1989) have also demonstrated that ice-sheet variability during the Matuyama Chronozone $(2.47-0.73 \mathrm{Ma})$ occurred primarily at the $41 \mathrm{k} . \mathrm{y}$. periodicity. Here we explore the results of atmospheric General Circulation Models (GCM's) and paleoclimatic evidence from east Africa to suggest a mechanism for the origin of the 2.4-Ma shift in the Arabian Sea eolian record.

The variations in eolian supply indicated by the susceptibility data are most probably reflecting variations in source area aridity and not the strength of the summer monsoon. Based on a $400-k$.y. record of terrigenous (eolian) accumulation and terrigenous grain-size variations for an Owen Ridge piston core, Clemens and Prell (in press) have demonstrated that the record of terrigenous supply reflects variations in source area aridity, whereas the grain-size variations are reflecting changes in monsoon strength, and that these two indicators have very different frequency-domain characteristics. More importantly, Clemens and Prell demonstrated that the $400-k . y$. record of terrigenous accumulation was coherent and in phase with the $\delta^{18} \mathrm{O}$ stratigraphy over all orbital bands, providing strong evidence for a linkage between high-latitude ice sheets and Asian monsoon dust source areas.

\section{Atmospheric General Circulation Model Results}

Northeast Africa and Arabia have been identified as the probable dust source areas for the summer monsoon (Sirocko and Sarnthein, 1989), and general circulation model experiments have suggested that these regions may have experienced significant aridification when ice sheets were more extensive than today. Rind (1987) has examined the climatic effects of LGM ice sheets alone by comparing the results of a Goddard Institute for Space Studies (GISS) GCM experiment configured with full LGM conditions (i.e., LGM ice cover, solar insolation, sea level, and sea-surface temperatures) with an identically configured experiment except that the ice sheets were retained at their present (i.e., reduced) areal extent. His results demonstrate that the inclusion of LGM ice in the model causes dramatic cooling $\left(-5^{\circ}\right.$ to $\left.-10^{\circ} \mathrm{C}\right)$ and significant rainfall decreases (1-2 $\mathrm{mm}$ /day) over northeast Africa, Arabia, and Mesopotamia during the winter months (December-February). This is apparently a direct result of the downstream advection of cooler, drier air from the high-latitude Fennoscandian ice sheets.

The implication of this result is that monsoon dust source areas are subject to enhanced aridification during times of increased high-latitude ice-sheet cover, and the late Pleistocene paleoclimate data from this region support this relationship (e.g., Clemens and Prell, in press; Bonnefille and Riollet, 1988). An important caveat is that the precipitation field for this region is sensitive to western Indian Ocean sea-surface temperatures (SST). Several GCM studies have shown that warmer SST's can supply moisture to the monsoon dust source areas (Gates, 1976; Manabe and Hahn, 1977; Kutzbach and Otto-Bliesner, 1982; Prell and Kutzbach, 1987; Rind, 1987).

\section{East African Paleoclimate Records}

There is a wealth of terrestrial paleoclimate data from northeast Africa that suggest a transition to a regionally cooler, drier climate at $\sim 2.4 \mathrm{Ma}$. The occurrence of hominid fossils in the late Pliocene lacustrine and deltaic sediments of rift valley basins in Tanzania, Kenya, and Ethiopia has prompted detailed analyses of the floral and faunal compositions of these sediments. The strongest evidence for east African cooling and drying at $2.4 \mathrm{Ma}$ is based on palynological data from diatomite sediments at Gadeb (Ethiopian Highlands), where a vegetation descent of at least 1-1.5 km has been demonstrated to occur at some point between two radiometrically dated tuff layers at 2.51 $\mathrm{Ma}$ and 2.35 Ma (Bonnefille, 1983). The Gadeb pollen data 


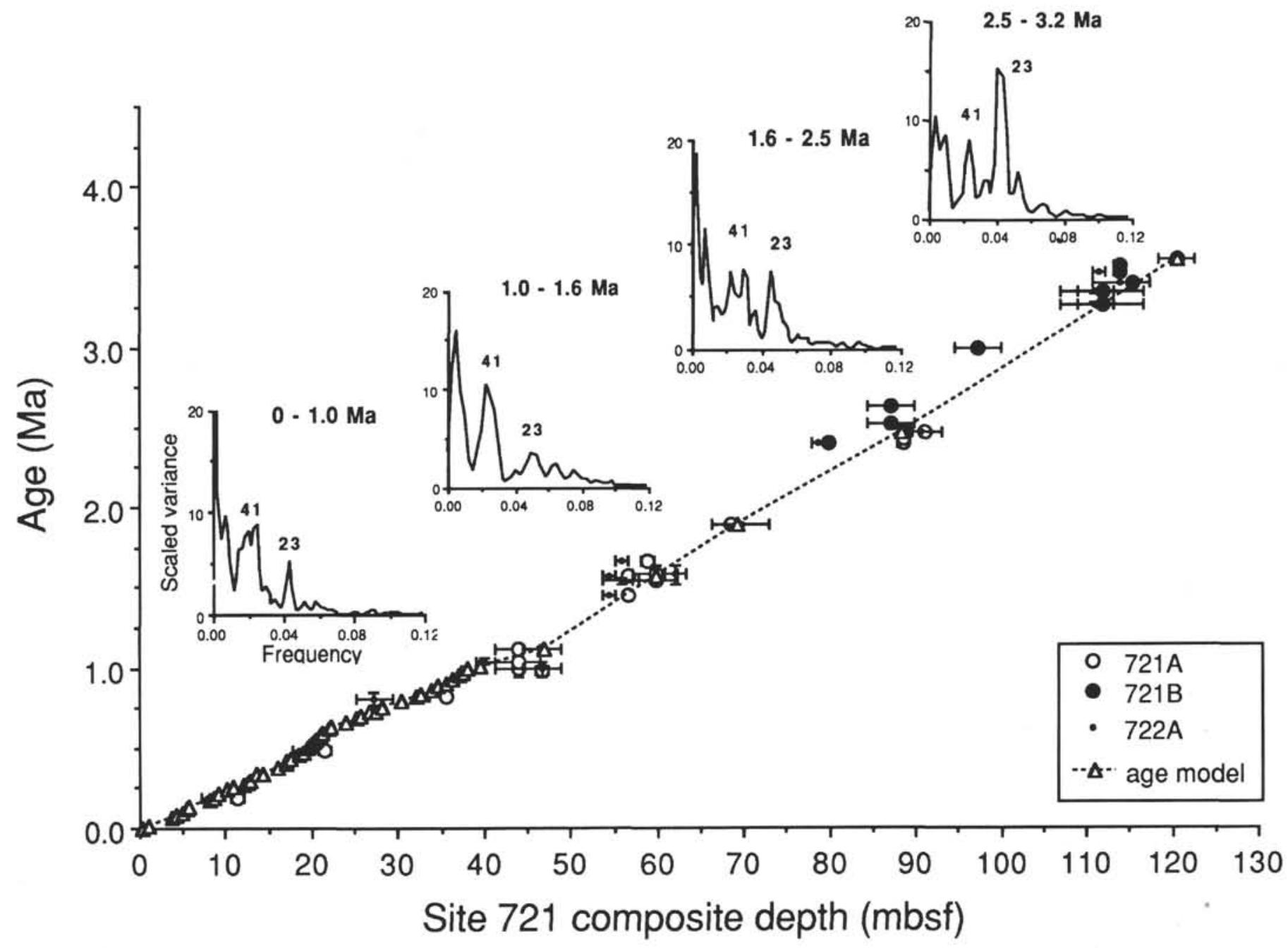

Figure 7. Age-depth relations for the Site 721 composite sequence. Age datums from Holes 721A, 721B, and 722A were transferred to their appropriate depths in the Site 721 composite sequence so that a maximum number of datums (46) could be used to determine the preliminary age model shown by the triangles and dotted line. Oxygen isotope data were used to determine age-depth relations to $1.0 \mathrm{Ma}$ (Clemens and Prell, this volume); these datums are listed in Table 2. Power spectra of the susceptibility data were calculated for four separate intervals: 0-1.0 Ma, 1.0-1.6 Ma, 1.6-2.5 Ma, and 2.5-3.2 Ma (bandwidth $=0.004$ ). Note that the data vary predominantly at orbital periodicities, and that these periodicities are nonstationary over the $3.2 \mathrm{Ma}$ record.

(at $2300 \mathrm{msl}$ ) show an abundance of shrub, heath, and grass (largely Ericaceae and Gramineae) pollen types which are found today only in the cooler montane climate above $3500 \mathrm{msl}$. The temperature decrease is equivalent to $\sim 4^{\circ}-6^{\circ} \mathrm{C}$ (Bonnefille, 1983). This shift to regionally cooler and drier conditions at 2.4 $\mathrm{Ma}$ is also supported by pollen data from lower Omo, near Lake Turkana, where there is a coeval expansion of savanna grasslands (Bonnefille, 1976). Bonnefille and Letouzey (1976) have shown that fossil wood and fruits with rainforest affinities disappeared from the lower Omo region at about this time. Abell (1982) and Cerling et al. (1977) have presented stable isotopic evidence from Lake Turkana gastropods and pedogenic carbonate horizons that also support a trend toward reduced precipitation between two radiometrically dated tuffs at 3.2 Ma and 1.9 Ma.

Macrofaunal evidence also supports a shift to more arid conditions near this time. Vrba (1985) has noted the appearance of new (peripheral) open grassland species of gazelle, antelope, bush pig, rhinoceros, and other bovids at $2.4 \mathrm{Ma}$. Wesselman (1985) has shown that fossil micromammals found in Omo Valley sediments shift to an open grassland assemblage near 2.4
Ma. There is also a marked development in hominid evolution near this time; the separation of Homo from the Australopithicus lineage and the development of robust Australopithicines occurred between 2.5 Ma and 2.4 Ma (Grine, 1986). The larger cranial capacity and stone tool-making capabilities of $H$. habilis distinguish it from the Australopithicus lineage and, although the timing of this separation remains inexact, several authors have speculated that these characteristics may have been an evolutionary response to increased food-gathering competition as lowland forests were gradually replaced by sparser savanna vegetation (see Bonnefille, 1976; Grine, 1986).

\section{CONCLUSIONS}

Whole-core magnetic susceptibility was measured at 5-cm intervals on cores from Sites 721 and 722 positioned $\sim 9.5 \mathrm{~km}$ apart on an elevated ridge in the Arabian Sea. The data were used to construct complete composite sequences for each site extending to $\sim 3.2 \mathrm{Ma}$. The records from the two sites are essentially identical, suggesting that local erosion and sediment redistribution is not important. 
Table 2. The age-depth datums used to establish the preliminary age model shown in Figure 7."

\begin{tabular}{|c|c|c|c|}
\hline $\begin{array}{c}\text { Site } 721 \\
\text { composite } \\
\text { depth (mbsf) }\end{array}$ & Core & Age (Ma) & Source \\
\hline 0.150 & $722 \mathrm{~B}-1 \mathrm{H}-1,10$ & 0.006 & Hole $722 \mathrm{~B}$ Oxygen-isotopic data \\
\hline 1.000 & $722 \mathrm{~B}-1 \mathrm{H}-1,100$ & 0.018 & (Clemens and Prell, this vol.) \\
\hline 3.600 & $722 \mathrm{~B}-1 \mathrm{H}-3,30$ & 0.065 & (Clemens and Prell, this vol.) \\
\hline 4.150 & $722 \mathrm{~B}-1 \mathrm{H}-3,80$ & 0.080 & (Clemens and Prell, this vol.) \\
\hline 4.870 & $722 \mathrm{~B}-1 \mathrm{H}-3,120$ & 0.099 & (Clemens and Prell, this vol.) \\
\hline 5.420 & $722 \mathrm{~B}-1 \mathrm{H}-4,20$ & 0.122 & (Clemens and Prell, this vol.) \\
\hline 5.800 & 722B-2H-1, 15 & 0.135 & (Clemens and Prell, this vol.) \\
\hline 8.250 & $722 \mathrm{~B}-2 \mathrm{H}-2,60$ & 0.171 & (Clemens and Prell, this vol.) \\
\hline 8.600 & $722 \mathrm{~B}-2 \mathrm{H}-2,110$ & 0.183 & (Clemens and Prell, this vol.) \\
\hline 9.250 & $722 \mathrm{~B}-2 \mathrm{H}-3,40$ & 0.218 & (Clemens and Prell, this vol.) \\
\hline 10.100 & $722 \mathrm{~B}-2 \mathrm{H}-3,40$ & 0.238 & (Clemens and Prell, this vol.) \\
\hline 10.800 & $722 \mathrm{~B}-2 \mathrm{H}-4,50$ & 0.249 & (Clemens and Prell, this vol.) \\
\hline 12.150 & 722B- $2 \mathrm{H}-5,20$ & 0.269 & (Clemens and Prell, this vol.) \\
\hline 12.650 & $722 \mathrm{~B}-2 \mathrm{H}-5,60$ & 0.287 & (Clemens and Prell, this vol.) \\
\hline 12.800 & $722 \mathrm{~B}-2 \mathrm{H}-5,100$ & 0.299 & (Clemens and Prell, this vol.) \\
\hline 13.500 & $722 \mathrm{~B}-2 \mathrm{H}-6,10$ & 0.331 & (Clemens and Prell, this vol.) \\
\hline 14.300 & $722 \mathrm{~B}-2 \mathrm{H}-6,100$ & 0.341 & (Clemens and Prell, this vol.) \\
\hline 16.050 & $722 \mathrm{~B}-3 \mathrm{H}-1,40$ & 0.375 & (Clemens and Prell, this vol.) \\
\hline 16.950 & $722 \mathrm{~B}-3 \mathrm{H}-1,140$ & 0.405 & (Clemens and Prell, this vol.) \\
\hline 17.100 & $722 \mathrm{~B}-3 \mathrm{H}-2,10$ & 0.423 & (Clemens and Prell, this vol.) \\
\hline 17.650 & $722 \mathrm{~B}-3 \mathrm{H}-2,70$ & 0.434 & (Clemens and Prell, this vol.) \\
\hline 18.650 & $722 \mathrm{~B}-3 \mathrm{H}-3,40$ & 0.461 & (Clemens and Prell, this vol.) \\
\hline 19.050 & $722 \mathrm{~B}-3 \mathrm{H}-3,80$ & 0.471 & (Clemens and Prell, this vol.) \\
\hline 19.500 & $722 \mathrm{~B}-3 \mathrm{H}-3,140$ & 0.491 & (Clemens and Prell, this vol.) \\
\hline 19.700 & $722 \mathrm{~B}-3 \mathrm{H}-4,30$ & 0.513 & (Clemens and Prell, this vol.) \\
\hline 20.000 & $722 \mathrm{~B}-3 \mathrm{H}-4,80$ & 0.524 & (Clemens and Prell, this vol.) \\
\hline 20.150 & $722 \mathrm{~B}-3 \mathrm{H}-4,110$ & 0.538 & (Clemens and Prell, this vol.) \\
\hline 20.600 & $722 \mathrm{~B}-3 \mathrm{H}-4,130$ & 0.552 & (Clemens and Prell, this vol.) \\
\hline 20.900 & $722 \mathrm{~B}-3 \mathrm{H}-5,5$ & 0.563 & (Clemens and Prell, this vol.) \\
\hline 21.050 & $722 \mathrm{~B}-3 \mathrm{H}-5,20$ & 0.574 & (Clemens and Prell, this vol.) \\
\hline 21.220 & $722 \mathrm{~B}-3 \mathrm{H}-5,60$ & 0.596 & (Clemens and Prell, this vol.) \\
\hline 21.950 & $722 \mathrm{~B}-3 \mathrm{H}-5,140$ & 0.617 & (Clemens and Prell, this vol.) \\
\hline 22.350 & $722 \mathrm{~B}-3 \mathrm{H}-6,30$ & 0.628 & (Clemens and Prell, this vol.) \\
\hline 23.950 & $722 \mathrm{~B}-3 \mathrm{H}-7,20$ & 0.656 & (Clemens and Prell, this vol.) \\
\hline 25.100 & $722 \mathrm{~B}-4 \mathrm{H}-1,60$ & 0.689 & (Clemens and Prell, this vol.) \\
\hline 25.650 & $722 \mathrm{~B}-4 \mathrm{H}-1,120$ & 0.700 & (Clemens and Prell, this vol.) \\
\hline 26.750 & $722 \mathrm{~B}-4 \mathrm{H}-2,90$ & 0.721 & (Clemens and Prell, this vol.) \\
\hline 27.500 & $722 \mathrm{~B}-4 \mathrm{H}-3,10$ & 0.731 & (Clemens and Prell, this vol.) \\
\hline 28.250 & $722 \mathrm{~B}-4 \mathrm{H}-3,100$ & 0.756 & (Clemens and Prell, this vol.) \\
\hline 30.400 & $722 \mathrm{~B}-4 \mathrm{H}-5,40$ & 0.797 & (Clemens and Prell, this vol.) \\
\hline 32.200 & $722 \mathrm{~B}-4 \mathrm{H}-6,50$ & 0.817 & (Clemens and Prell, this vol.) \\
\hline 32.650 & $722 \mathrm{~B}-4 \mathrm{H}-6,90$ & 0.839 & (Clemens and Prell, this vol.) \\
\hline 33.770 & $722 \mathrm{~B}-4 \mathrm{H}-7,50$ & 0.861 & (Clemens and Prell, this vol.) \\
\hline 34.550 & 722B-5H-1, 60 & 0.881 & (Clemens and Prell, this vol.) \\
\hline 35.570 & $722 \mathrm{~B}-5 \mathrm{H}-2,30$ & 0.899 & (Clemens and Prell, this vol.) \\
\hline 36.300 & $722 \mathrm{~B}-5 \mathrm{H}-2,120$ & 0.921 & (Clemens and Prell, this vol.) \\
\hline 36.950 & $722 \mathrm{~B}-5 \mathrm{H}-3,40$ & 0.948 & (Clemens and Prell, this vol.) \\
\hline 37.450 & $722 \mathrm{~B}-5 \mathrm{H}-3,110$ & 0.971 & (Clemens and Prell, this vol.) \\
\hline 38.100 & $722 \mathrm{~B}-5 \mathrm{H}-4,30$ & 0.988 & (Clemens and Prell, this vol.) \\
\hline 39.450 & 722B-5H-5, 20 & 1.004 & (Clemens and Prell, this vol.) \\
\hline 46.950 & $721 \mathrm{~B}-5 \mathrm{H}-5,130$ & 1.110 & nannofossil datum \\
\hline 59.700 & $721 \mathrm{C}-7 \mathrm{H}-5,0$ & 1.570 & nannofossil datum \\
\hline 69.200 & $721 \mathrm{C}-8 \mathrm{H}-4,0$ & 1.900 & nannofossil datum \\
\hline 78.450 & $721 \mathrm{~B}-8 \mathrm{H}-7,30$ & 2.120 & "Tuned datum"b \\
\hline 88.300 & $721 \mathrm{C}-10 \mathrm{H}-3,100$ & 2.470 & Matuyama/Gauss \\
\hline 120.300 & $721 B-13 X-5,140$ & 3.540 & nannofossil datum \\
\hline
\end{tabular}

a The datums from 0 to $1.0 \mathrm{Ma}$ are based on an oxygen-isotopic stratigraphy for Hole 722B (Clemens and Prell, this volume). Other datums were derived by determining the "center" of the bio- or magnetostratigraphic datum clusters (see Figure 7).

b This datum was not used to calculate initial time-series or power spectra (Figs. 8 and 9).

Terrigenous extraction analyses indicate that susceptibility is an accurate proxy indicator of terrigenous fraction variations. An eolian origin for the magnetic susceptibility variations is supported by strong correlations with quartz $(0.83)$ and dolomite (0.70). Calculations of terrigenous and biogenic component fluxes demonstrate that the susceptibility variations are reflecting variations in terrigenous flux, not dilution by variations in biogenic flux.

\section{Site 721}

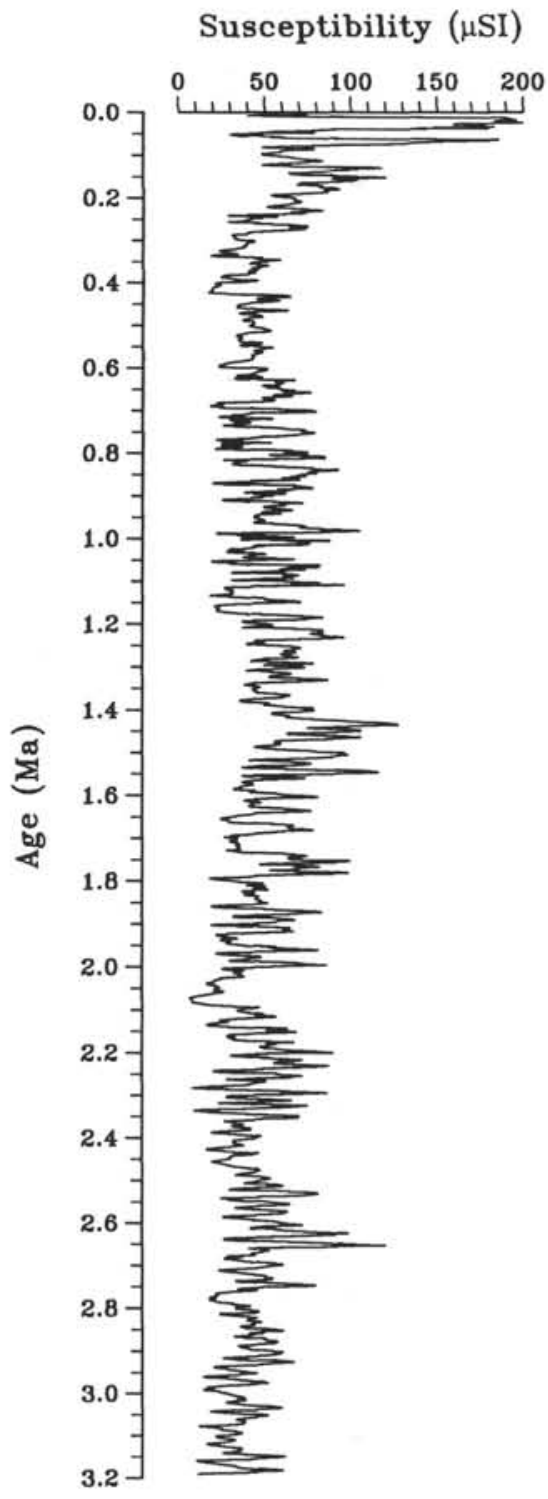

Figure 8 . The magnetic susceptibility time-series based on the age model shown in Figure 7.

Spectral analysis of the susceptibility time-series demonstrates that variance is largely concentrated at orbital bands. Using a phase-lock approach, the precessional component (23-19 k.y.) of the susceptibility record from 3.2 to $1.6 \mathrm{Ma}$ is shown to be highly coherent with calculated orbital precession.

Spectral analysis of discrete $400 \mathrm{k} . \mathrm{y}$. intervals indicates that the susceptibility variations are nonstationary. Prior to $2.4 \mathrm{Ma}$ the data vary predominantly at the $23-19$ k.y. periodicities; after 2.4 Ma power at the 23-19 k.y. band remains high, but there is a significant increase in power at the $41 \mathrm{k} . \mathrm{y}$. periodicity.

The coincidence of the shift observed at $2.4 \mathrm{Ma}$ with the rapid expansion of high-latitude ice sheets suggests a linkage between high- and low-latitude climate. Results from atmospheric general circulation models suggest that monsoonal dust source areas in northeast Africa and Arabia experience aridification with expanded high-latitude ice cover, and published floral and faunal evidence from northeast Africa suggests that this region 


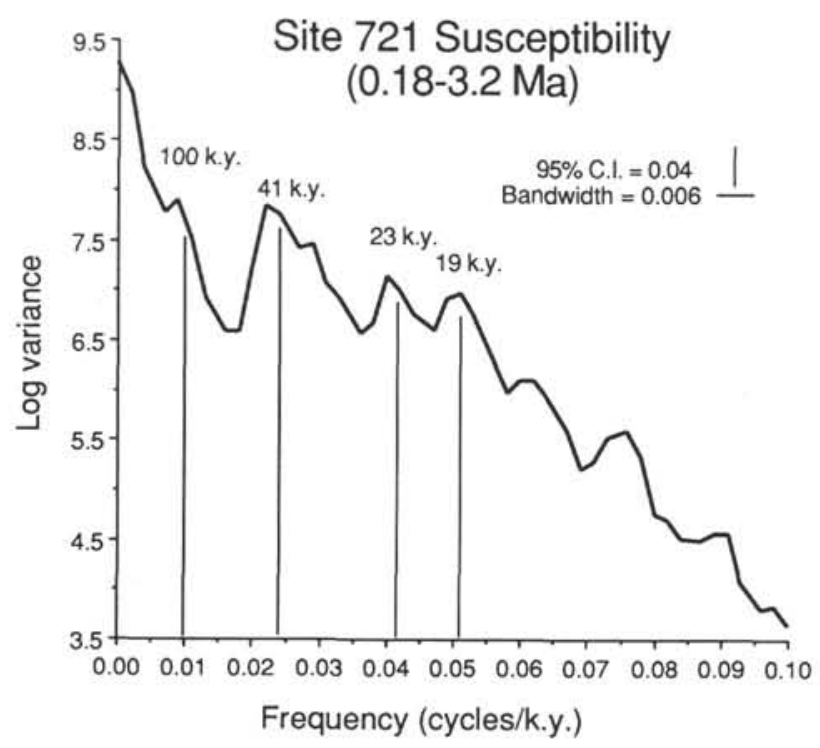

Figure 9. Power spectral estimates of the susceptibility time-series shown in Figure 8 (the uppermost 180 k.y. of the record was excluded). Note that much of the variance is centered at orbital periodicities.

was cooler and more arid at this time. We propose that the shift to increased 41 k.y.-power after $2.4 \mathrm{Ma}$ reflects modulation of monsoon dust source area aridity (and dust delivery to the Arabian Sea) by high-latitude ice-sheet cover that varied predominantly at this periodicity.

\section{ACKNOWLEDGMENTS}

Bill Ruddiman was very helpful in the initial design of this project and his suggestions greatly improved this manuscript. We gratefully acknowledge the efforts of numerous Leg 117 scientists who helped with the tedious susceptibility measurements. We thank Rebecca Esmay and Bettina Domeyer for their assistance in the terrigenous extraction and XRD laboratory work; computing facilities were provided by the Borehole Research Group. W. Broecker, D. Kent, R. Fairbanks, P. Olsen, S. Clemens, and D. Murray are acknowledged for their comments and suggestions; W. Ruddiman and two anonymous reviewers are thanked for their critical reviews. This research was supported by funding from USSAC and by National Science Foundation grant number OCE-89-11206. This is Lamont-Doherty Geological Observatory publication number 4585 .

\section{REFERENCES}

Abell, P. I., 1982. Paleoclimates at Lake Turkana, Kenya, from oxygen isotope ratios of gastropod shells. Nature, 297:321-323.

Berger, A. L., 1978. Long-term variations of caloric solar insolation resulting from earth's orbital variations. Quat. Res. N.Y., 9:139-167.

Berger, A. L., 1984. Accuracy and frequency stability of the Earth's orbital elements during the Quaternary. In Berger, A., Imbrie, J., Hayse, J., Kukla, G., and Saltzman, B. (Eds.), Milankovitch and Climate (Pt. 1): Dordrecht (D. Reidel), 3-39.

Berger, A. L., and Pestiaux, P., 1984. Accuracy and stability of the Quaternary terrestrial insolation. In Berger, A., Imbrie, J., Hayse, J., Kukla, G., and Saltzman, B. (Eds.). Milankovitch and Climate (Pt. 1): Dordrecht (D. Reidel), 83-111.

Bloemendal, J., 1983. Paleoenvironmental implications of the magnetic characteristics of sediments from DSDP Site 514, southeast Argentine Basin. In Ludwig, W. J., Krasheninnikov, V. A., et al., Init. Repts. DSDP, 71: Washington (U.S. Govt. Printing Office), 10971108.

Bloemendal, J., and deMenocal, P., 1989. Evidence for a shift in the climatic variability of the African and Asian monsoons at $2.5 \mathrm{Ma}$ : an application of whole-core magnetic susceptibility measurements to paleoclimatology. Nature, 342:897-899.

Bloemendal, J., Lamb, B., and King, J., 1988. Paleoenvironmental implications of rock-magnetic properties of late Quaternary sediment cores from the eastern equatorial Atlantic. Paleoceanography, 3:6187.

Bonnefille, R., 1976. Palynological evidence for an important change in the vegetation of the Omo basin between 2.5 and $2.0 \mathrm{Ma}$. In Coppens, Y., et al. (Eds.), Earliest Man and Environments in the Lake Rudolf Basin: Chicago (Univ. Chicago Press), 421-431.

1983. Evidence for a cooler and drier climate in the Ethiopian uplands, $2.5 \mathrm{Ma}$ ago. Nature, 303:487-491.

Bonnefille, R., and Letouzey, R., 1976. Fruits fossiles D'Antrocaryon dans la vallée de l'Omo (Ethiopie). Adansonia, 16:65-82.

Bonnefille, R., and Riollet, G., 1988. The Kashiru pollen sequence (Burundi) paleoclimatic implications for the last 40,000 yr B.P. in tropical Africa. Quat. Res. N.Y., 30:19-35.

Canfield, D. E., and Berner, R. A., 1987. Dissolution and pyritization of magnetite in anoxic marine sediments. Geochim. Cosmochim. Acta, 51:645-659.

Cerling, T. E., Hay, R. L., and O'Neil, J. R., 1977. Isotopic evidence for dramatic climate changes in east Africa during the Pleistocene. Nature, 267:137-138.

Chester, R., Sharples, E. J., and Sanders, G. S., 1985. The concentration of particulate aluminium and clay minerals in aerosols from the northern Arabian Sea. J. Sediment. Petrol., 55:37-41.

Clemens, S. C., and Prell, W. L., in press. Late Pleistocene variability of Arabian Sea summer monsoon winds and dust source aridity: an eolian record from the lithogenic component of deep-sea sediments. Paleoceanography.

deMenocal, P., Laine, E., and Ciesielski, P., 1988. A magnetic signature of bottom-current erosion. Phys. Earth Planet. Inter., 51:326-348.

Doh, S.-J., King, J., and Lienen, M., 1988. A rock-magnetic study of GPC-3 from the central North Pacific and its paleoceanographic implications. Paleoceanography, 3:89-112.

Dunlop, D., 1973. Superparamagnetic and single-domain threshold sizes in magnetite. J. Geophys. Res., 78:1780-1793.

Froelich, P. N., Klinkhammer, G. P., Bender, M. L., Luedtke, N. A., Heath, G. R., Cullen, D., Dauphin, P., Hartman, B., Hammond, D., and Maynard, V., 1979. Early oxidation of organic matter in pelagic sediments of the eastern Equatorial Atlantic: suboxic diagenesis. Geochim. Cosmochim. Acta, 43:1075-1090.

Gates, W. L., 1976. Modelling the Ice Age climate. Science, 191:11381144.

Goldberg, E. D., and Griffin, J. J., 1970. The sediments of the northern Indian Ocean. Deep-Sea Res., 17:513-537.

Grine, F. E., 1986. Ecological causality and the pattern of Plio-Pleistocene hominid evolution in Africa. S. Afr. J. Sci., 82:87-89.

Hahn, D. G., and Manabe, S., 1975. The role of mountains in the South Asian monsoon circulation. J. Atmos. Sci., 32:1515-1541.

Hastenrath, S., 1985. Climate and the Circulation of the Tropics: Boston (D. Reidel).

Hastenrath, S., and Lamb, P. J., 1979. Climatic Atlas of the Indian Ocean. Surface Climate and Atmospheric Circulation (Vol. 1): Madison, WI (Univ. Wisconsin Press), 116.

Henshaw, P. C., Jr., and Merrill, R. T., 1980. Magnetic and chemical changes in marine sediments. Rev. Geophys. Space Phys., 18:483504.

Imbrie, J., Shackleton, N. J., Pisias, N. G., Morley, J. J., Prell, W. L., Martinson, D. G., Hays, J. D., McIntyre, A., and Mix, A. C., 1984. The orbital theory of Pleistocene climate: support from a revised chronology of the marine O-18 record. In Berger, A. L., Imbrie, J., Hayse, J., Kukla, G., and Saltzman, B. (Eds.), Milankovitch and Climate (Pt. 2): Dordrecht (D. Reidel), 269-305.

Karlin, R., and Levi, S., 1983. Diagenesis of magnetic minerals in recent hemipelagic sediments. Nature, 303:327-330.

Kent, D. V., 1982. Apparent correlation of paleomagnetic intensity and climatic records in deep-sea sediments. Nature, 299:538-539.

Kent, D. V., and Lowrie, W., 1974. Origin of magnetic instability in sediment cores from the central North Pacific. J. Geophys. Res., 49: 2987-3000.

Kolla, V., and Biscaye, P., 1977. Distribution and origin of quartz in the sediments of the Indian Ocean. J. Sediment. Petrol., 47:642-649. 
Kolla, V., Henderson, L., and Biscaye, P., 1976. Clay mineralogy and sedimentation in the western Indian Ocean. Deep-Sea Res., 23:949961.

Kolla, V., Kostecki, J. A., Robinson, F., Biscaye, P. E., and Ray, P. K., 1981. Distribution and origins of clay minerals and quartz in surface sediments of the Arabian Sea. J. Sediment. Petrol., 51:563-569.

Kutzbach, J. E., 1981. Monsoon climate of the early Holocene: climate experiment with the earth's orbital parameters for 9000 years ago. Science, 214:59-61.

Kutzbach, J. E., and Otto-Bliesner, B. L., 1982. The sensitivity of the African-Asian monsoonal climate to orbital parameter changes for 9000 years B.P. in a low-resolution General Circulation Model. $J$. Atmos. Sci., 39:1177-1188.

Lowrie, W., and Heller, F., 1982. Magnetic properties of marine limestones. Rev. Geophys. Space Phys., 20:171-192.

Manabe, S., and Hahn, D. G., 1977. Simulation of the tropical climate of an ice age. J. Geophys. Res., 82:3889-3911.

Martinson, D. G., 1982. An inverse approach to signal correlation with applications to deep-sea stratigraphy and chronology [Ph.D. dissert.]. Columbia Univ., New York.

Martinson, D. G., Menke, W., and Stoffa, P., 1984. An inverse approach to signal correlation. J. Geophys. Res., 87:4807-4818.

McClure, H. A., 1976. Radiocarbon chronology of the Quaternary lakes in the Arabian Desert. Nature, 263:755.

Mead, G. A., Tauxe, L., and LaBrecque, J. L., 1986. Oligocene paleoceanography of the South Atlantic: paleoclimatic implications of sediment accumulation rates and magnetic susceptibility. Paleoceanography, 1:273-284.

Nair, R. R., Ittekkot, V., Manganini, S. J., Ramaswamy, V., Haake, B., Degens, E. T., Desai, B. N., and Honjo, S., 1989. Increased particle flux to the deep ocean related to monsoons. Nature, 338:749-751.

Pokras, E. M., and Mix, A. C., 1985. Eolian evidence for spacial variability of late Quaternary climates in tropical Africa. Quat. Res. N. Y., 24:137-149.

Prell, W. L., 1984. Monsoonal climate of the Arabian Sea during the late Quaternary: a response to changing solar radiation. In Berger, A. L., Imbrie, J., Hayse, J., Kukla, G., and Saltzman, B. (Eds.). Milankovitch and Climate (Pt. 1): Dordrecht (D. Reidel), 349-366.

Prell, W. L., and Kutzbach, J. E., 1987. Monsoon variability over the past 150,000 years. J. Geophys. Res., 92:8411-8525.

Prell, W. L., and Van Campo, E., 1986. Coherent response of Arabian Sea upwelling and pollen transport to late Quaternary monsoonal winds. Nature, 323:526-528.

Prospero, J. M., 1981. Arid regions as sources of mineral aerosols in the marine atmosphere. Geol. Soc. Am. Spec. Pap., 186:71-86.

Pye, K., 1987. Aeolian Dust and Dust Deposits: London (Academic Press).

Ramage, C. S., 1965. The summer atmospheric circulation over the Arabian Sea. J. Atmos. Sci., 23:144.

Raymo, M. E., Ruddiman, W. F., Backman, J., Clement, B. M., and Martinson, D. G., 1989. Late Pliocene variation in Northern Hemisphere ice sheets and North Atlantic deep water circulation. Paleoceanography, 4:413-446.

Rea, D. K., and Janecek, T. R., 1981. Mass accumulation rates of the non-authigenic, inorganic, crystalline (eolian) component of deepsea sediments from the western mid-Pacific Mountains, DSDP Site 463. In Theide, J., Vallier, T. L., et al. Init. Repts. DSDP, 62: Washington (U.S. Govt. Printing Office), 653-659.
Rind, D., 1987. Components of the Ice Age circulation. J. Geophys. Res., 92:4241-4281.

Robinson, S. G., 1986. The late Pleistocene record of North Atlantic deep-sea sediments revealed by mineral-magnetic measurements. Phys. Earth Planet. Inter., 42:22-47.

Ruddiman, W. F., Raymo, M. E., Martinson, D. G., Clement, B. M. and Backman, J., 1989. Pleistocene evolution: northern hemisphere ice sheets and the North Atlantic Ocean. Paleoceanography, 4:353412.

Ruddiman, W. F., Raymo, M. E., and McIntyre, A., 1986. Matuyama 41,000-year cycles: North Atlantic Ocean and northern hemisphere ice sheets. Earth Planet. Sci. Lett., 80:117-129.

Shackleton, N. J., Backman, J., Zimmerman, H., Kent, D. V., Hall, M. A., Roberts, D. G., Schnitker, D., Baldauf, J., Desprairies, A., Homrighausen, R., Huddlestun, P., Keene, J. B., Kaltenback, A. J., Krumsiek, K.A.O., Morton, A. C., Murray, J. W., and WestbergSmith, J., 1984. Oxygen isotope calibration of the onset of ice-rafting in DSDP Site 552A: history of glaciation in the North Atlantic region. Nature, 307:620-623.

Singh, G., Joshi, R. D., and Singh, A. B., 1972. Stratigraphic and radiocarbon evidence for the age and development of three salt lake deposits in Rajasthan, India. Quat. Res. N.Y., 2:496-505.

Sirocko, F., and Sarnthein, M., 1989. Wind-borne deposits in the northwestern Indian Ocean: record of Holocene sediments versus modern satellite data. In Leinen, M., and Sarnthein, M. (Eds.), Paleoclimatology and Paleometeorology: Modern and Past Patterns of Global Atmospheric Transport. NATO ASI Ser., 401-433.

Stewart, R., Pilkey, O., and Nelson, B. W., 1965. Sediments of the northern Arabian Sea. Mar. Geol., 3:411-427.

Street-Perrott, F. A., and Harrison, S. P., 1984. Temporal variations in lake levels since 30,000 years B.P.: an index of the global hydrological cycle. In Hansen, J. E., and Takahashi, T. (Eds.): Climate Processes and Climate Sensitivity. Am. Geophys. Union, 29.

Suc, J.-P., 1984. Origin and evolution of the Mediterranean vegetation and climate in Europe. Nature, 307:429-432.

Swain, A. M., Kutzbach, J. E., and Hastenrath, S., 1983. Estimates of Holocene precipitation for Rajasthan, India based on pollen and lake-level data. Quat. Res. N.Y., 19:1-17.

Thompson, R., Bloemendal, J., Dearing, J. A., Oldfield, F., Rummery, T. A., Stober, J. C., and Turner, G. M., 1980. Environmental applications of magnetic measurements. Science, 207:481-486.

Thompson, R., and Oldfield, F., 1986. Environmental Magnetism. London (Allen \& Unwin).

Van Campo, E., 1983. Paleoclimatologie des Bordures de la mer dArabie depuis 150,000 ans: analyse pollinique et stratigraphie isotopique [Ph.D. thesis]. Univ. des Science et Techniques du Languedoc.

Van Campo, E., Duplessy, J. C., and Rossignol-Strick, M., 1982. Climatic conditions deduced from a 150-k.y. oxygen isotope-pollen record from the Arabian Sea. Nature, 296:56-59.

Vrba, E. S., 1985. African Bovidae: evolutionary events since the Miocene. S. Afr. J. Sci., 81:263-266.

Wesselman, H. B., 1985. Fossil micromammals as indicators of climatic change about 2.4 m.y. ago in the Omo Valley, Ethiopia. S. Afr. J. Sci., 81:260-261.

Date of initial receipt: 24 August 1989

Date of acceptance: 20 February 1990

Ms 117B-178 


\section{Site 721}

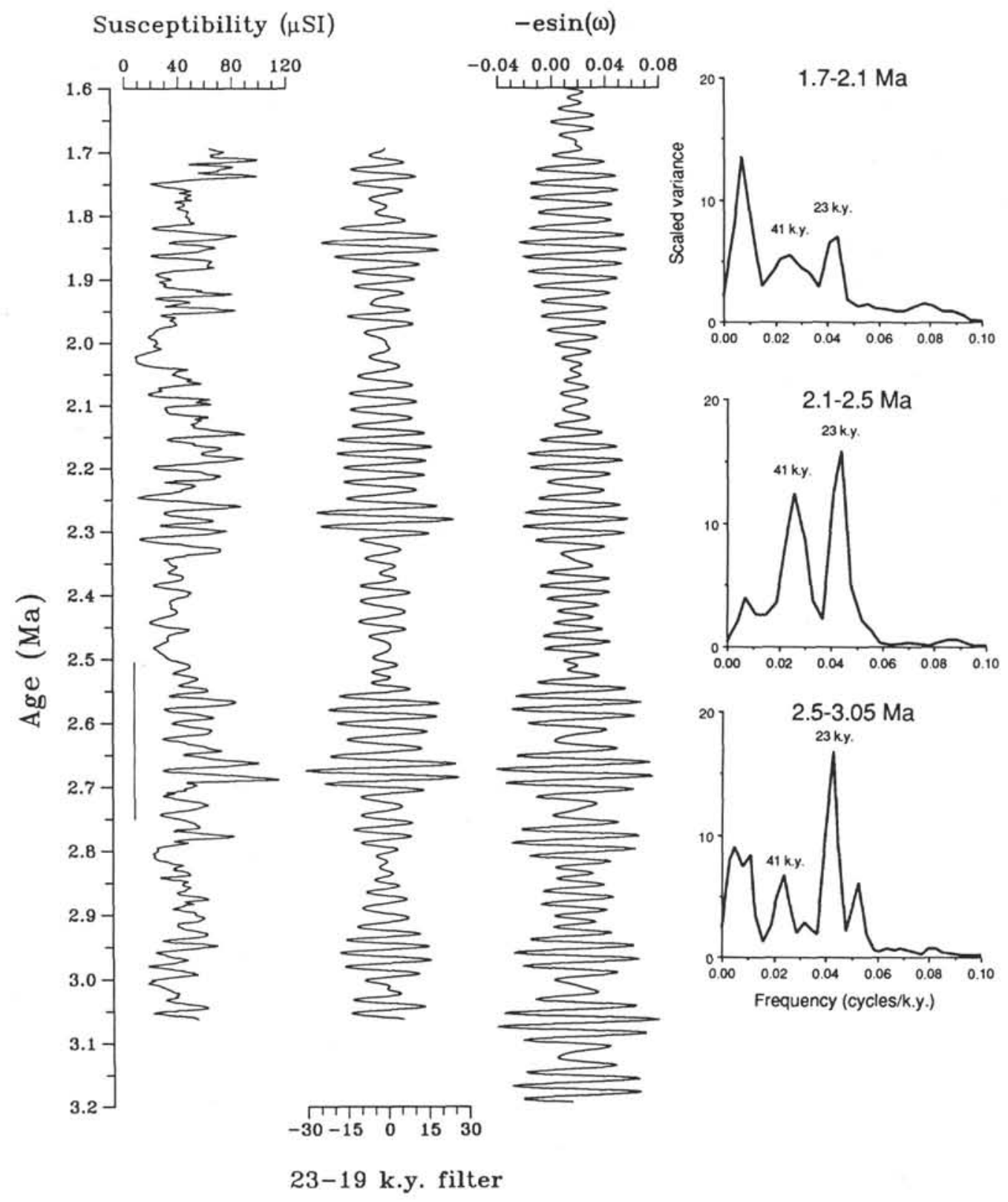

Figure 10. Calculated precession $(-e \sin (\omega))$, the 23-19 k.y. band-pass filter of the susceptibility record, and the raw susceptibility record for the 3.2-1.6 Ma interval. The filtered susceptibility data were correlated (phaselocked) to precession using a signal correlation package (Martinson et al., 1984) to investigate the degree of coherency between the presumed isolation forcing $(-e \sin (\omega))$ and the climate response (susceptibility). The coherency is particularly high $(0.89)$ between precession and the filtered susceptibility over the $3.2-2.5$ Ma inter$\mathrm{val}$, the coherency of the entire 3.2-1.6 Ma interval is 0.86. Power spectra are shown for three intervals (3.2-2.5 $\mathrm{Ma}, 2.5-2.1 \mathrm{Ma}$, and 2.1-1.6 Ma) to demonstrate the increase in $41 \mathrm{k} . \mathrm{y}$. power after $2.5 \mathrm{Ma}$ (bandwidth = 0.004). The vertical line to the left shows the interval selected for the flux calculations described in the text and shown by Figures 13-15. 


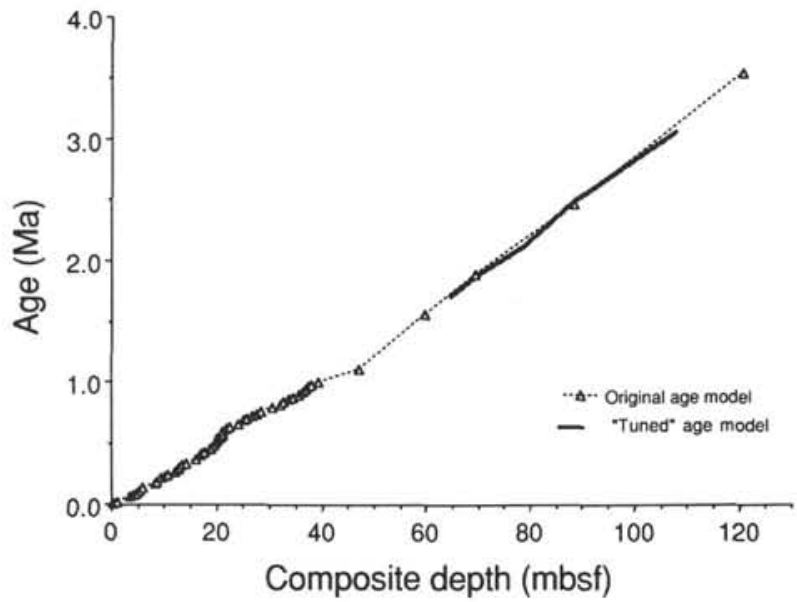

Figure 11. Comparison of the preliminary age model of Figure 8 with the "tuned" age model shown in Figure 10. 

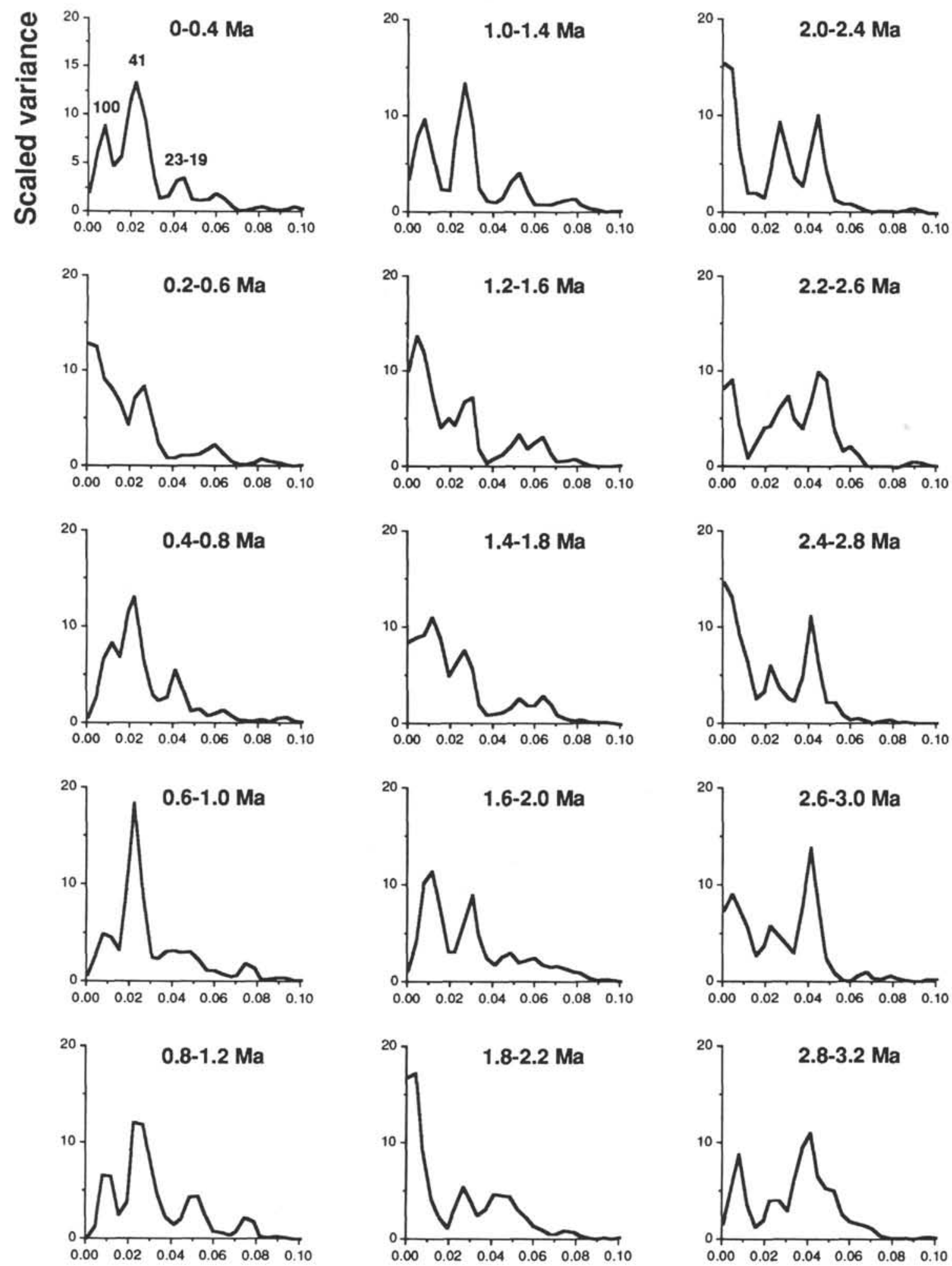

Frequency (cycles/k.y.)

Figure 12. Power spectra calculated for overlapping 400 k.y. segments of the susceptibility time series. Note that the first increase in $41 \mathrm{k} . \mathrm{y}$. power occurs in the 2.2-2.6 Ma window and is fully represented in the 2.0-2.4 Ma window, indicating that the shift takes place at $\sim 2.4 \mathrm{Ma}$. 

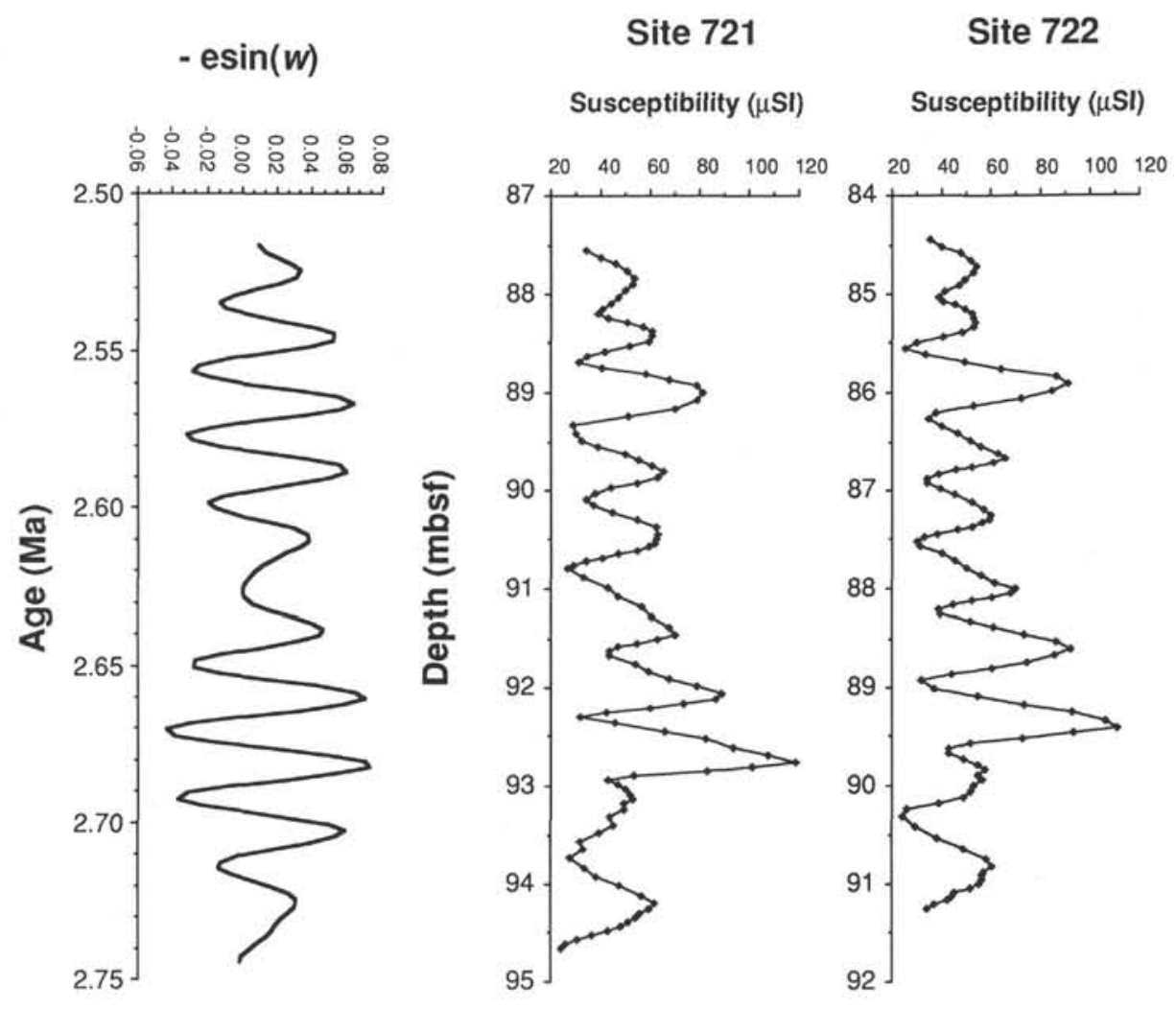

Figure 13. Calculated precession $(-e \sin (\omega))$ for $2.75-2.55 \mathrm{Ma}$ and the raw susceptibility data from the Site 721 and 722 composite records that correspond to this time interval. 

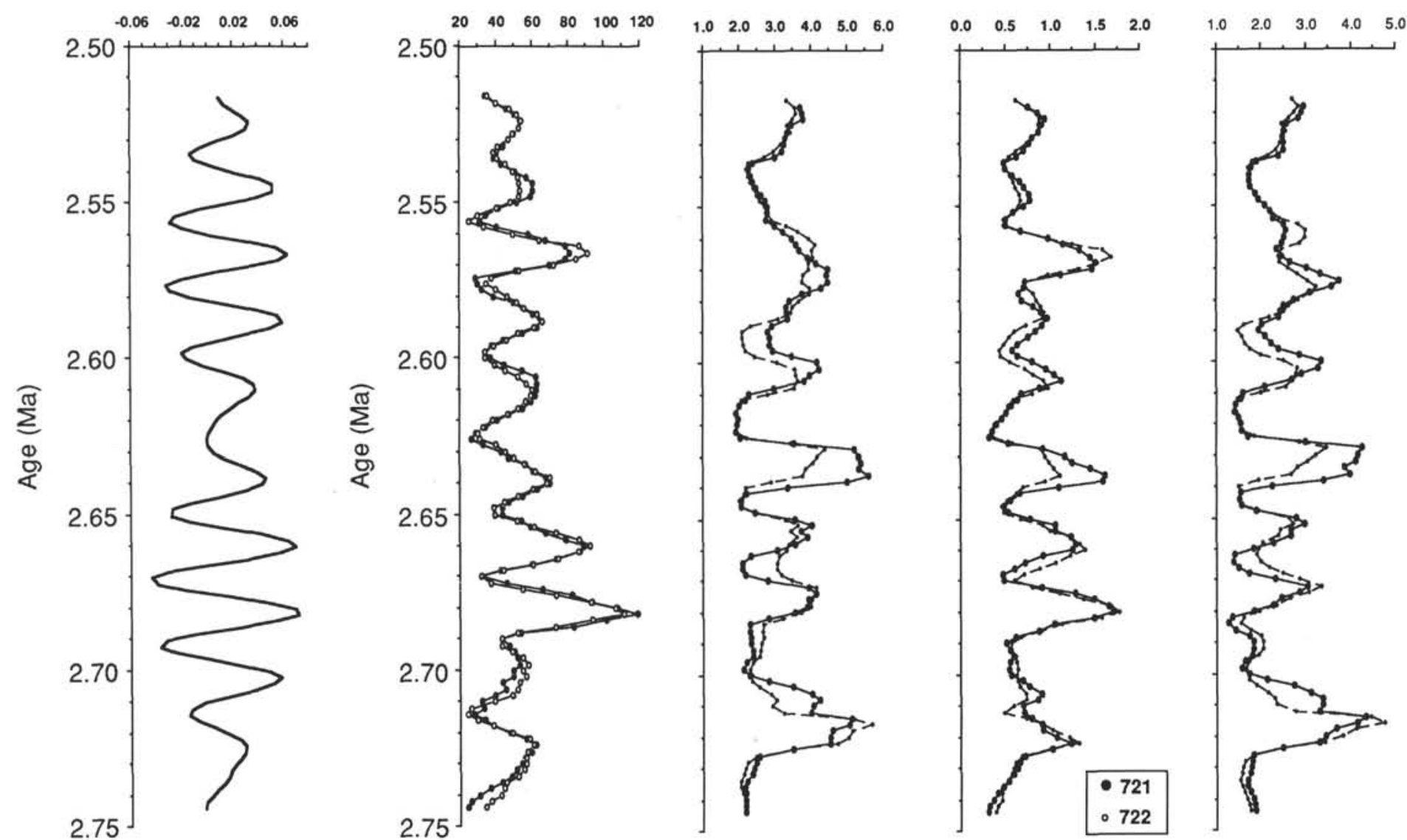

Figure 14. Terrigenous and biogenic component flux calculations based on the "tuned" time scale (2.75-2.55 Ma). Susceptibility data from Sites 721 and 7222 were correlated to orbital precession and variations in sedimentation rate were calculated and used to determine downcore mass accumulation rates. The similar data between sites suggests that the results are real and not site-dependent. Terrigenous and biogenic accumulation rates were calculated using the terrigenous-susceptibility regression equation shown in Figure 6. 
A
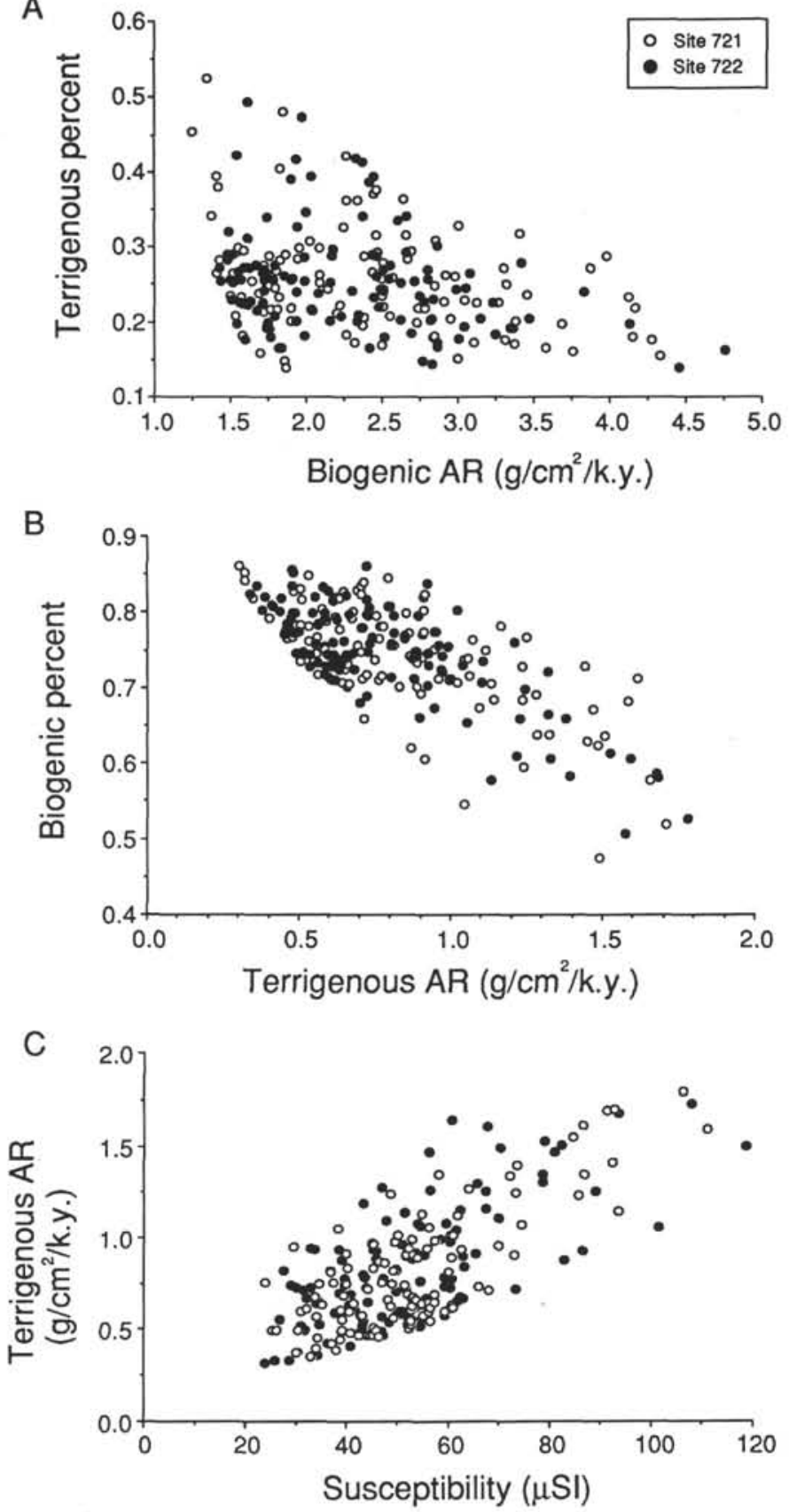

Figure 15. Terrigenous accumulation plotted against biogenic percent (A) and biogenic accumulation plotted against terrigenous percent (B). The inverse correlation of (A) indicates that variations in terrigenous input are responsible for the observed biogenic (terrigenous) fraction variations. The weak correlation of $(\mathbf{B})$ indicates that biogenic accumulation is not primarily responsible for the observed terrigenous fraction variations. Susceptibility is positively correlated (C) to terrigenous accumulation rate. 